\title{
Good Death Within Its Historical Context and as a Contemporary Challenge: A Philosophical Clarification of the Concept of "Euthanasia"
}

\author{
Josef Kuře \\ University Centre for Bioethics \& Department of Medical Ethics, \\ Masaryk University, Brno \\ Czech Republic
}

\section{Introduction}

The word euthanasia evokes emotions, regardless of the way it is used. When pronounced, instead of a rational discourse, separate camps of irreconcilable proponents and opponents are drawn up. Both fight for dignity, liberty, autonomy, rights and humaneness. Few debates in the area of health care result in such polarization of opinions as euthanasia. While for some people euthanasia is a manifestation of the individual's autonomy equal with a responsible control of one's destiny, a compassionate responsiveness to someone's immense suffering or a clinical imperative to act in the patient's best interest, for other people, euthanasia is tantamount to or merely a euphemism for killing, the violation of human life and an infringement of the human right to life, being contradictory to the sanctity of life doctrine and facilitating the abuse of vulnerable persons. The controversies surrounding the moral acceptability of euthanasia and its decriminalization are characteristic of the intellectual confrontations in medical ethics and in public debates during the last decades of the twentieth century and they remain a challenge for our ageing societies in the twenty first century. As Keown (2002, p. 9) points out, "given the absence of any universally agreed definition of 'euthanasia' it is vital to be clear about how the word is being used in any particular context. The cost of not doing so is confusion." This confusion is, among others, created by semantic substitutions in which euthanasia is not distinguished from "physician assisted dying", from "assisted suicide" or from "physician assisted suicide" (Quill \& Battin, 2004; Young, 2007), or being simply replaced by very general terms like "assisted death" (Lewis, 2007; Lewy, 2011), under which not only euthanasia but also assisted suicide is usually subsumed. The general public, especially in countries other than ones such as the Netherlands or Belgium, use general terms such as "assisted death" or "assisted dying" while generally not differentiating between euthanasia and assisted suicide, not understanding euthanasia in the sense used by legislation in countries where euthanasia has been legalized. This use of a broad notion of euthanasia results in various clinical situations being discussed under the scope of "euthanasia".

Once euthanasia is merged with "assisted death", then under the term "euthanasia" similar but distinct clinical situations such as medical futility, life sustaining treatment, 
categorization of therapy, palliative care, and other end-of-life decisions are discussed (van der Maas, 1991; Onwuteaka-Philipsen, 2003). Decisions in palliative and intensive care medicine include a much broader spectrum of ethical dilemmas than the issue of euthanasia alone (Battin et al., 2007; Kinzbrunner \& Policzer, 2010). Nevertheless it happens quite frequently that two people, discussing whether 'euthanasia' is morally good and/or right and whether it should be legalized or not understand two quite different things by the same term; they fail to connect, developing two parallel monologues. Such fruitless and frustrating occurrences are characteristic of many euthanasia debates. It was one such occasion that inspired the author to study the historical semantics of euthanasia, the results of which are presented below. ${ }^{1}$

Since the notion of euthanasia is loaded by strong feelings, many euthanasia discussions lack clear semantic ground as a rational starting point. So instead of semantic clarification (status questionis in the traditional philosophical discourse), euthanasia discussions are often limited to the justification of their arguments (regardless if pro or contra) and to the critique of the arguments of the other side as a matter of principle.

This situation is further exasperated by both opponents and proponents of euthanasia often using the same arguments but with very diverse meanings. Based on the same argument, completely contrary conclusions can be drawn. Such is the case with arguments based on human dignity. One can state that euthanasia violates human dignity and therefore it should be prohibited. However, another can argue that not allowing legal euthanasia violates human dignity since one then has to die in a way which harms dignity; therefore euthanasia is a death which fully corresponds to human dignity (the law which regulates assisted suicide in Oregon State is entitled the Death With Dignity Act).

Should the euthanasia discussion be meaningful, a conceptual clarification needs to be one of the primary conditions of such a discussion. I'm arguing that prior to any argumentation either for or against euthanasia, the semantics used in such argumentations has to be clarified. "It is important to understand what euthanasia is. No one disputes the fact that euthanasia is a form of killing; so too are murder, manslaughter, suicide, capital punishment, and war. To state that each is a form of killing warns us to

\footnotetext{
1 This chapter was written thanks to a well-known surgeon and distinguished professor's contribution to euthanasia, a presentation at a conference called "The Philosophy of Euthanasia", which both frustrated and challenged me. This motivated me to write an article in the form of a philosophical explanation of the notion of euthanasia (Kuře, 2007). The text provided here is an extended English revision. Here is a synopsis of his presentation, which took the form of a story and a conclusion. In the mountains lived a forester who lived a happy life up to the moment when he went down to a local hospital. Having been diagnosed with cancer, he returned back to his house in the forest and shot himself to death. Conclusion: euthanasia has to be legalized. So ends the surgeon's contribution.

A typical case of suicide. One isn't able to bear a depressing and burdensome situation. Under intensive stress one sees the best way out of such a situation as one's own death, accomplishing it by one's own hand, without any external help (an unassisted death). Such a person did not ask for the termination of his life, no other person was involved. In was suicide, not euthanasia; not even assisted suicide. Besides cancer there can be many different reasons for which one might commit suicide. This story illustrates the kind of conceptual inaccuracy that can be in play. The forester was not suffering extreme pain, and he could possibly have been cured. If his story is an argument for euthanasia then any trying situation in life would qualify for euthanasia, leading euthanasia to be a first and not last resort. While most would argue that one is free to commit suicide any time he/she assesses his/her life as a burden and meaningless. But suicide has here nothing to do with euthanasia.
} 
proceed with care, but it need not to be decisive in determining the rightness or wrongness of the act. We need, therefore, to address the question of what it is about euthanasia that distinguishes it from, or places it in a separate category to, say, self-killing or murder." (Draper, 1998, p. 176).

Even a discussion which distinguishes between euthanasia and suicide is not necessarily free of conceptual inexactitudes by using terms such as "active euthanasia", "passive euthanasia", "direct euthanasia", "indirect euthanasia", "help in dying" as synonyms for euthanasia, "mercy killing" (German "Gnadentod") as another synonym for euthanasia, and other terms such as "voluntary euthanasia", "involuntary euthanasia", active action causing death (actio commissionis), passive action (non-acting) causing death (actio ommissionis), "killing", "letting die" ("allowing to die"), usage of "ordinary" /"extraordinary" means, "intending death", "foreseeing death" (to foresee that an unintended death will occur). Not only is the term "euthanasia" connected with considerable semantic unclearness, but it is also used and abused in various cultural and historical contexts - so for instance, in Germany the term "euthanasia" (Euthanasie) is used to refer to the abuse of the Nazi regime during that period (eugenic euthanasia), while the term "Sterbehilfe" 2 is used in current euthanasia debates.

This use of unspecified terminology - with the term "good death" being used to subsume many very diverse situations and meanings - and including the use of single terms with diverse connotations (e.g. "assisted death" or "dignity") is quite common in these debates. So semantic clarifications are therefore a necessary prerequisite for any ethical reflection on euthanasia to take place. However one of the obstacles for a meaningful discussion of euthanasia is its semantic deficiency. The non-addressed polysemantism that is present hinders understanding, reinforcing superficiality and creating misapprehensions. For instance if one makes use of the old-fashioned "active" and "passive" euthanasia terms, which can still be found in the literature, then the use of one and the same denotation, namely "euthanasia", for ethically entirely different situations (killing by high doses of opiates and allowing to die when the terminally ill person is dying, without causing dysthanasia) is considerably problematic - not only from the semantic point of view.

The aim of this chapter is to contribute to the clarification of the concept of "good death" as it appeared throughout history; its goal is to clarify what was meant by the term "euthanasia" in various historical periods. The chapter does not seek to provide "a short history of euthanasia" but to show how differently and in which semantic, cultural and philosophical frameworks the term "euthanasia" has been used in the course of history. So instead of a comprehensive history of euthanasia, a search for diverse typologies of euthanasia through history will be conducted. It seems that it is necessary to start not with the $18^{\text {th }}$ century and with the "right to die" $^{3}$ as Ian Dowbiggin does (2007) but with Classical thinking. Nevertheless, Dowbiggin clearly demonstrates euthanasia's affinity to suicide,

\footnotetext{
2 The term "Sterbehilfe" is ambiguous in concept; it can be used in quite contrary meanings. In one meaning it is used as an equivalent term for active euthanasia (help to die) (Bobbert, 2003; Eibach, 1998; Eid, 1985; Müller, 1997; Ritzel, 1998). While in its other meaning "Sterbehilfe" refers to the active support of a dying person (palliative care, human accompaniment for the dying patient) (Michalsen \& Reinhart, 2006; Kruse \& Wagner, 1986; Pöltner, 2006; Simon, 2003; Sporken, 1988, 1990).

${ }^{3}$ Cf. Cavan, 2000; Downing \& Smoker, 1986; Ferguson, 2007; Humphry \& Wickett, 1986; Sunstein, 1997; Wilshaw, 1974.
} 
which can be conceptualized in many ways. There were times, particularly in Christian Europe, when the fear of Hell was far greater than the fear of death. He also demonstrates that distinctions are worthwhile in a historical approach to euthanasia. 4 This chapter does not delve into the status quo of the current euthanasia debate, nor does it provide moral or ethical "for" or "against" arguments as used within euthanasia debates. Rather it tries to illustrate the diverse backgrounds of such debates.

The methodology used in this chapter is not a pure historical overview of the notion of euthanasia. The purpose of the historical survey conducted here is to contribute to a better "contemporary reading" of the concept called "euthanasia". This approach presumes that such a historical and semantic survey can help one to understand the contemporary challenges of the technified, highly advanced and dehumanized biomedicine of our postindustrial and postmodern society. Euthanasia today is being discussed in the context of numerous other clinical and societal issues such as medical futility, patient autonomy, physician integrity, physician assisted suicide, terminal sedation, patient's rights, social death preceding biological death, increasing health care costs and palliative care. Many of the present medical circumstances such as withholding or withdrawing treatment and other life sustaining treatments have created new therapeutic situations, questioning the traditional goals of medicine.

Methodologically this chapter combines differentiated semantics with a critical history of philosophy. Within a historical survey it shows different meanings of the term "euthanasia", from a peaceful and nonviolent death to death by request and unrequested mercy killing. The goal here is to demonstrate the broad semantic spectrum of euthanasia. The search for historical semantics will be governed by the idea of "good death" and its relation to the present problems in health care, with a specific regard to current euthanasia issues. Once the notion of "good death" has been clarified, the ethics of euthanasia can be well-founded.

As a result of the historical survey, the main semantic typologies of euthanasia will be presented, e.g. peaceful natural death (Suetonius), voluntary suicide (autothanatos, Stoa), medically accompanied dying without life prolongation (euthanasia exteriori), social euthanasia, eugenic euthanasia, "easy death" and in/voluntary euthanasia. Furthermore, the recent semantic and analytical discussions on euthanasia will be summarized and their implications for ethics discussions will be outlined. In addition, the importance of some of the philosophical background discussions for the conceptual understanding of euthanasia (e.g. human rights) will be highlighted.

\section{Common desire as the common ground}

In etymological terms, the word "euthanasia" in Classical Greek means "good death" ( $\varepsilon \dot{v}=$ good, $\theta$ ávatos = death). With respect to the polysemantics of the adjective $\varepsilon \dot{v}$, one could, as the proper equivalent to the term "euthanasia", interpret it to mean not only "good death" but also expressions like "nice death", "beautiful death", "happy death", "lucky death", or in a tropological sense also "mild death", "easy death", "peaceful death", "nonviolent

\footnotetext{
${ }^{4}$ Notwithstanding the fecund contribution of Dowbiggin's historical study (2007), it overlooks two needed aspects: clear distinctions and more distance in evaluation. One would expect from a historian that he would write in the sense of the old historians' rule sine ira et studio.
} 
death" or "painless death". 5 From an etymological point of view, it is obvious that "euthanasia" is not primarily about something so specific as administrating a deadly injection upon a patient's request but about the concept of a "good death".

There is a general consensus at this semantic level: as we are mortal, probably everybody, excluding those with psychopathologies, wishes to die a "good death". From this

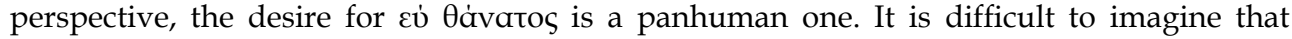
someone without a pathological disorder would wish any other death than عi Đávatos in its original meaning. What does vary, where we differ, and remaining a lasting subject of controversy, is the context of this عं. All disagreements regarding euthanasia are disputes about the "good", what kind of death is a good one, what are the characteristics of a "good death". Why does the denotation "good" cause such a strong diversity of options, implacable contrapositions and ripples of emotions? There is an easy answer to this question: because such a denotation of "good" is related to the basic concepts of life, to the fundamental values, philosophical views, metaphysical and religious beliefs and a priori positions. Therefore the context of this "good" in its relation to death will be examined.

\section{Concepts of "a good death": A historical overview}

First let's look at how the concept of "a good death" has been understood over the history of philosophical thinking, which values, circumstances and actions have been assigned to this concept and how it has been conditioned by cultural, historical, social and religious factors. It is very important to note that the discussions about euthanasia in the $21^{\text {st }}$ century and the good death controversy are nothing new and that these discussions have been going on within a historical context that started in the Classical era. (Brody, 1989). However, the current context of the euthanasia debate with regard to the present stage and form of medicine is new, different and peerless. (Vanderpool, 2004). The controversial concept of euthanasia has to be investigated not only with regard to what has been attributed to the adjective "good" but foremost with regard to attitudes towards death as such. The following research provides an overview of the different concepts of "good death" over the course of history, stemming from attitudes towards death in general, which, throughout our history and beyond the controversies about "good death", has been a more common source of human angst.

\subsection{Antiquity}

The concept of euthanasia does not start with Bacon as some people believe but with ancient Greek thinking. The term cú Oávatos first appears in Hellenic literature side by side with the term ż́yipta (giras = old age). Initially looming sporadically, later a similar concept called mors bona ${ }^{6}$ (good death) appears in Roman literature. The term mors bona denominates an honest and happy way of dying. Felici vel honesta morte mori (to die in a lucky and honest way) was an ancient ideal.

Already in mythological times, sleep was regarded as the brother of death. In the Odyssey, Homer lets the healthy and old citizens of the utopian island Siri die in a painless and quick

\footnotetext{
${ }^{5}$ In modern Greek عن்日avaoia not only means "mild death" or "painless death" but also "famous death" or "glorious death".

${ }^{6}$ L. A. Seneca, Epistulae 67,9.
} 
way: they are "saved" by the god Apollo, who kills them peacefully. In this way euthanasia was often perceived as the best gift that one could get from the gods. (Mystakidou et al., 2005). In the Classical period, in some regions, Greek citizens used to end their lives after obtaining the consent of the community. As part of eugiria (to grow old in a "good" way) and to prevent a life of senility and weakness, illness and fragility, they used to prefer the abandonment of life en masse by drinking hemlock within a "last festivity", being regarded in such as heroes by the community. (Mystakidou et al., 2005). In Ancient Greece there was generally a positive attitude towards suicide.

When Plato describes the death of Socrates (Phaidon), who prefers hemlock to exile, he notes that Socrates' act was in fact a good death. In cases where abnormality was identified, for the good of the individual citizens and for the good of the polis (society), these sick citizens were left to die. Plato justifies this in Politeia 7 : those who have bad (unhealthy) bodies have to be abandoned to die, those who have a bad (unhealthy) and irremediable soul have to be killed. ${ }^{8}$

In Antiquity, two traditions can be traced: one originating with Hippocrates and his school (Corpus Hippocraticum), and the other founded on Greek and Roman philosophy, in particular on the teachings of Plato, Aristotle and the Stoics. The Hippocratic tradition, whose core is the Hippocratic Oath, prohibits the killing of a human being, just as it forbids any aid in suicide (in present-day terminology in "physician assisted suicide"): "To please no one will I prescribe a deadly drug nor give advice which may cause his death." Euthanasia as a direct killing of the patient, regardless if upon his/her request or without any request, is not forbidden by the Hippocratic Oath directly. But such a prohibition can be deduced, a fortiori, from the prohibition of any help in suicide. So euthanasia as the killing of a patient by the physician is not in accordance with either the Hippocratic Oath or the spirit of the Hippocratic tradition. Within this tradition, health is regarded as one of the highest forms of good. So the intentional termination of a patient's life is discordant with Hippocratic medical practice, dedicated to caring for the health and life of people. Features typical of the Hippocratic tradition are a preventive and therapeutic approach to the medical art. Prevention has to protect and preserve the wellbeing of the healthy, while therapy has to return the sick to health. An integral part of this approach to the medical art is that of limitation, which has to be accepted: where no cure is available and where the patient has already been overwhelmed by disease, there no therapy should be attempted. In this case treatment should not be started, any protraction of the life of a deadly ill person was held to be inconsistent with the medical ethos. ${ }^{9}$ The Hippocratic tradition, based on a Pythagorean sect and on ancient Greek mythological polytheism in which the gods were both protectors and proprietors of human beings, later resonated with Jewish and Christian teaching according to which God is the master who possesses dominion over life; human beings receive life as a gift. The concept of "good death" in its original version as an ancient tradition is based on a mythological sacredness of life. A modified version of this concept survived not only to the Middle Ages but to Modern Era.

The second source of the concept of euthanasia was philosophical tradition, which produced certain tension due to its contrast to the Hippocratic tradition. While the Hippocratic

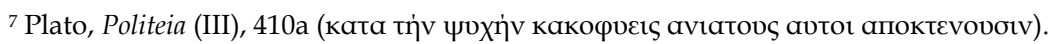

${ }^{8}$ Although this passage in Politeia is interpretatively disputable, one can educe from this passage that euthanasia as (regardless if merciful or pragmatic) killing could be morally justifiable.

${ }^{9}$ Hippocrates, Of Art (VI, 3). In: Hippocrates, 1923, Vol. 2, p. 193.
} 
tradition prohibits euthanasia as a form of killing and likewise bans physician assisted suicide, philosophers such as Plato, Aristotle and the Stoics approved of the killing of seriously and/or incurably sick patients who consume the resources of the community (polis); either the community should abandon care of them or they should be killed outright. A similar destiny, for the good the community, they held, should encounter handicapped and seriously ill children. This can be seen in the practise of the laws of Sparta: newborn children were brought to an examination which had to prove the viability of the child; any child evaluated as non-viable was killed. For Plato, a human being is the possession of the gods and suicide is a contradiction to this concept, but the gods approved of suicide in cases where the necessity to die is evident (e.g. the death of Socrates). The next sphere of exceptions which justify suicide is, according to Plato, the shame of extreme suffering, poverty, or disaster, akin to supreme deprivation and dishonour or irreversible disgrace of fate. Plato, in the Laws (Nomoi) exhorts to take flight from a society of bad people and to appreciate everything that is beautiful and fair. And if one cannot escape from heavily incorrigible maleficence or from unredeemable crimes, then it is more beautiful to choose death and to depart from life. ${ }^{10}$ For those who find themselves in an incurable state which can be interpreted as "sickness of the soul", it is better not to live any longer. By their departure from life they would benefit others twofold: first they would become an admonitory example which warns from doing injustice; secondly the community would be free of those people. ${ }^{11}$ The aforementioned tracts of Plato's Laws refer to both suicide and to the capital punishment.

For Aristotle death is the worst of all things. One can act towards death in a sublime and noble way, facing death courageously or spinelessly. Facing death, one also can commit injustice towards the community if one takes his/her own life. Moreover, according to Aristotle, the one who destroys him/her self suffers - as "state punishment" - a certain loss of civil rights on the ground that he/she has treated the state unjustly. The justification of this punishment is the correlation between the individual and community: if an individual treats him/her self unjustly, simultaneously he/she also treats the community unjustly. ${ }^{12}$ In his treatise on courage Aristotle speaks about the beautiful death the courageous person faces without any fear. ${ }^{13}$ Beautiful death can also be death in which a person gives up his own life without fear but also death which a person faces stoutly; such death is simultaneously good (aүäóv). However suicide seems to be contrary to such courage: to die to escape from a miserable situation such as poverty or pain is not the mark of a brave person, but rather of a coward. To fly from what is troublesome is softness and frailty. To

\footnotetext{
10 Plato, Nomoi (IX), 854c.

11 Plato, Nomoi (IX), 862e.

12 Aristotle, Nicomachean Ethics, V/15, 1138a.
}

Aristotle's argument about suicide as injustice towards the state (just acts are those in accordance with virtue prescribed by the law and since the law does not expressly permit suicide, and what it does not expressly permit it forbids, suicide is a violation of the law which harms others and therefore a person committing suicide is acting unjustly) was later adopted by Thomas Aquinas, who connected this argument with natural law.

13 "Now death is the most terrible of all things; for it is the end, and nothing is thought to be any longer either good or bad for the dead. But the brave man would not seem to be concerned even with death in all circumstances, e.g. at sea or in disease. [...] He will be called brave who is fearless in face of a noble

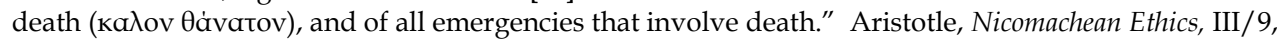
1115 a. 
commit suicide does not mean to endure death because it is noble but because one is trying to escape from evil. 14

While for Aristotle suicide is a sign of weakness, for Seneca suicide is a mark of sublimity. Seneca equates death to non-being: mors est non esse ${ }^{15}$, holding as sublime the termination of life in the face of the cruelty of disease or of people. This is valid in particular for the elite of society: it is more appropriate to terminate one's own life than to face humiliation, fear of the future, sickness or old age. ${ }^{16}$ The decision about autothanatos (suicide) is not a big decision, it is important to die in an honest, peaceful and courageous way. A substantial part of the stoical concept of a good death is serenity and equableness, ${ }^{17}$ one leaves composedly when the inevitable hour of death comes. ${ }^{18}$ Seneca also formulated a truth which is still valid and even more significant in our societies, where death has become taboo and something that has to be suppressed and curbed: Non mortem timemus sed cogitationem mortis (We do not fear death but the thinking on death). ${ }^{19}$

An exemplary good death in ancient times was that narrated of the death of the Roman emperor Augustus, who died at 75, and can be given as it was described by the historian Suetonius (69-122): “Then, having admitted his friends to his presence, he asked them whether they thought he had acted well his part on the stage of life [...]. After which, having dismissed them all, [...] he gave up the ghost. [...] Thus he died a very easy death, such as he himself had always wished for. For as often as he heard that any one had died quickly and without pain, he prayed that he and his might have the like euthanasia ${ }^{20}$, for that was the word he made use of." 21 Here in the term "euthanasia", the whole concept of the good death as the desirable and covetable way of dying is concentrated.

In this study Diogenes Laertius (3rd century) has been selected as the last ancient author on "good death".22 Voluntary death (mors voluntaria) is for him the expression of a rational concept of life. The honest reasons for a suicide lead a wise human in a good and rational

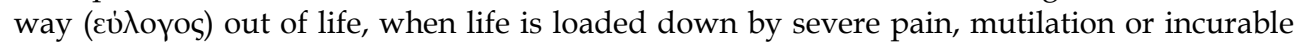
disease. ${ }^{23}$ Although incurable disease was at that time something different from incurable disease today (e.g. diabetes), the concept of mors voluntaria grounded on a good rational deliberation is in principle the same which is used in contemporary discussions on

14 Aristotle, Nicomachean Ethics, III/11, 1116a.

15 L. A. Seneca, Epistulae 54,4.

16 L. A. Seneca, Epistulae 58,36.

17 L. A. Seneca, Epistulae 67,9.

18 "Magna res est [...] cum adventat hora illa inevitabilis, aequo animo abire." (It is a great thing to leave with a serene spirit when the inevitable hour comes). (L. A. Seneca, Epistulae 30,4).

${ }^{19}$ Seneca, Epistulae 30,17.

${ }^{20}$ In this passage, the original Latin text is interrupted and the Greek word euthanasia is inserted: "Nam fere quotiens audisset cito ac nullo cruciatu defunctum quempiam, sibi et suis euthanasian similem (hoc enim et verbo uti solebat) precabatur." (Suetonius, De vitis ceasarum, II/99. Available at

http:/ / www.thelatinlibrary.com/suet.html, cited 20.03.2011.)

${ }_{21}$ Suetonius, Lives of the Twelve Caesars, II, 99 (Wordsworth Editions Limited, Ware, UK, 1997, p. 122)

${ }^{22}$ It has to be noted that from the $4^{\text {th }}$ century, the way death and euthanasia were perceived changed after Christianity became the state religion. After this point, both suicide and euthanasia as they were understood in Classical times became incompatible with Christianity and its fundamental assumptions, such as life seen as a gift from God, the decision about the moment of death belonging exclusively to God, lead to euthanasia being considered as a terrible sin.

${ }^{23}$ Diogenes Laertius, Vitae philosophorum, VII, 130. 
euthanasia - with the difference that mors voluntaria was understood as suicide. Arguments given in these ancient discussions for voluntary euthanasia (mors voluntaria) could be deduced by eulogos, by good rational considerations.

The introduced examples demonstrate that euthanasia in Antiquity was understood in several distinctly diverse meanings. In one line, from Plato to Seneca, euthanasia is equal to a legitimate killing of unwelcome people, of those with incurable diseases or with severe handicaps who, for the good of society, have to be abandoned or directly killed. This form of "good death" can be called social euthanasia. Individuals with certain features become a burden on society and since the capacity of the society cannot bear such a load the life of these individuals will be taken, directly or indirectly. The justification of such killing is not to be found in the autonomous choice or the good of those individuals suffering, but in the best interest of the society as a whole. It is the good of the society and society's best interest that constitutes the justification for such involuntary death. To them, this could be called "a

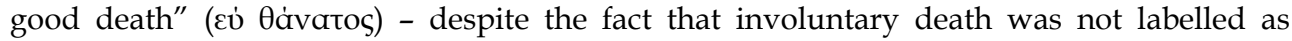
euthanasia as such in the Classical period. Therefore the term "social euthanasia" - whereby the good of the community overweighs the good of an individual - defines the good socially, not individually. Thus, such social euthanasia was perceived as a "good" death. One could argue that this is an ancient form of social utilitarianism.

The next meaning of euthanasia in Antiquity was mors voluntaria, voluntary death. In certain circumstances it was regarded not only as morally permissible to die a freely chosen death but even as morally right and desirable to do so in such circumstances. In this second sense, as it was an imperative to demonstrate courage, bravery and moral excellence (apetri) in one's daily life, when faced with a situation of experiencing humiliation, inhuman suffering or inconclusiveness of a given situation (such as heavy doom, unbearable suffering, incurable disease) to choose death was an expression of human freedom, dignity and nobility. Such termination of life was even used as a preventive measure against foreseeable humiliation such as impending capture or future fate caused by the weakness of old age or by a serious disease. Voluntary death, an optional death which was chosen as a free choice from the heart and mind of the person, without any external pressure, force or violence was regarded as a good death. In such a way has mors voluntaria been understood, by the Stoics in particular. One can argue that this voluntary and rational suicide was simultaneously euthanasia.

The third meaning of euthanasia in the ancient period was a peaceful, quick, easy and painless death. The best example for this hermeneutics of euthanasia is the death of the emperor Augustus. One could argue that in this sense euthanasia is a way of dying that everybody would probably appreciate.

Finally, we find the prohibition of euthanasia (induced death or assisted death) in the Hippocratic tradition. The reasoning for such a ban is the mythological understanding of human life: the gods are in charge of life and death, life is not completely at human disposal. More philosophical support for this idea would come from Plato's metaphysics, where life is regarded as one of the important forms of good, which embodies elements from the world of ideas. The Hippocratic tradition can be regarded as the ancient version of the later doctrine of the sanctity of life.

Compared to the ancient approaches to good death introduced here, euthanasia in our time is prevalently perceived as the painless termination of life (and suffering) by a physician. Today we distinguish euthanasia from natural death (the death the emperor Augustus died) and 
from (physician) assisted voluntary suicide. Euthanasia in Antiquity was associated with peaceful death and with mercy killing as well, despite the fact that mercy killing was not referred to as such. Nevertheless the concept of voluntary death as it appears in ancient times and as defined by the ancient term mors voluntaria bears some kinship to in the contemporary discussion of euthanasia. The Platonic tradition, despite the fact that Plato also deemed life as a gift of the gods and therefore beyond human intervention, can be seen as very supportive of the contemporary idea of euthanasia, even for unrequested (non-voluntary and involuntary) euthanasia. Plato's style of argumentation and decision-making is currently used not only in discussions but also in practise, such as the euthanasia of children or of incompetent patients. The Aristotelian tradition, however, is much more reserved about the rightness of suicide, focusing on the harm to society caused by a suicide. The Stoic tradition would fully support (assisted) suicide; and one can extrapolate that the Stoic tradition would also support contemporary (physician) assisted suicide and active euthanasia.

In sum, just as most aspects of modern civilization can trace its roots to Classical times, so too can the philosophical foundations and rudiments of our contemporary discussions on euthanasia. It is not only the modern concept of autonomy but also a broader philosophical and cultural tradition which has further enriched our current discussions. And one should be aware that we are today discussing issues which are new for our advanced biomedicine and for our postmodern society. However at the same time they are very old, they are ancient, and they have already been discussed in similar forms throughout the course of history. One can hope that an awareness of such a greater historical context will improve our understanding.

\subsection{The Middle Ages}

In the Middle Ages a common concept of good death was shared. This concept came from Biblical literature, in particular from Decalogue and in connection with Augustine's interpretation of the commandment "You shall not kill"24 where he equates suicide to homicide. ${ }^{25}$ Authors of the Middle Ages, for obvious reasons, do not deal with the issue of euthanasia as we handle it today. Yet they deal intensively with the question of killing, both the killing of another person (e.g. execution) or suicide. While in the first case, to differentiate, they allow killing in certain cases such as capital punishment (death as a penalty within retributive justice), in the case of suicide, they do not allow it, holding it unequivocally as morally wrong and sinful, and as fundamentally opposed to the Christian tradition. 26

Thomas Aquinas summarises the moral prohibition of suicide into the following three arguments:

\footnotetext{
24 "Quanto magis intellegendum est non licere homini se ipsum occidere, cum in eo, quod scriptum est: Non occides, nihilo deinde addito nullus, nec ipse utique, cui praecipitur, intellegatur exceptus!" (How much greater reason have we to understand that a man may not kill himself, since in the commandment "Thou shall not kill" there is no limitation added nor any exception made in favour, and least of all in favour of him on whom the command is laid.) - Augustinus Aurelius, De civitate Dei, I, 20. 25 "Non occides, nec alterum ergo nec te. Neque enim qui se occidit aliud quam hominem occidit." (Therefore you shall kill neither another nor yourself, for he who kills himself still kills nothing else than a human being.) - Augustinus Aurelius, De civitate Dei, I, 20.

${ }^{26}$ If suicide is a fundamental contradiction to the Christian tradition, then analogically such an evaluation is also valid for assisted suicide and about euthanasia as direct killing upon request.
} 
1. Suicide is against the natural law and against love.27

Suicide is not in harmony with the objective order, being in discrepancy to the natural law (lex naturalis). Therefore suicide is unnatural and naturally immoral. Moreover it is a vitiation of one's relation to oneself; it is natural to love oneself, to take care of oneself, to keep oneself alive and to resist any loss of life. Suicide is contrary to this natural inclination of man to preserve one's life.

2. Suicide is against society.

Building on Aristotle ${ }^{28}$, Aquinas, making use of the complexity argument, points out that suicide results in injury of the whole, i.e. society: every part, as such, belongs to the whole. As every human being is part of the community, and so, belonging to society. Therefore the one who commits suicide also injures the community (iniuriam communitati). ${ }^{29}$

3. Suicide is against God and against justice.

Because life is a gift from God, suicide means to take possession of life which is not owned and by nature cannot be owned by man. To usurp ownership of something that does not belong to one but that has been commended is an offence to justice. One can only decide about those things which belong to life but to decide about life as such is out of the scope of free human decisions. So no human can decide about departing from life. ${ }^{30}$

One can conclude that suicide is the worst of all terrible wrongdoings, devastation on all three levels of existence: suicide is against one's self (personal area), against society (societal area), and against the Divine order (transcendental area). So not only by Thomas Aquinas and other authors of the Middle Ages, but also by the later Christian churches, suicide was classified as one of the most grave of sins. Its gravity is based on the fact that it affects all areas, being an act "against all", enhanced by the fact that the person is now dead, without the possibility to regret and rectify. So not only medieval theologians but also many Christians in the coming centuries were horrified by the idea of suicide. Within the mentioned paradigm, one was not able to imagine anything more terrible than suicide. Consequently a heavy penalty for suicide was inevitable. Ipso facto the heaviest "temporal" and "eternal" punishments were applied; the committer was to be excluded from society (in

\footnotetext{
27 "...naturaliter quaelibet res seipsam amat, et ad hoc pertinet quod quaelibet res naturaliter conservat se in esse et corrumpentibus resistit quantum potest. Et ideo quod aliquis seipsum occidat est contra inclinationem naturalem, et contra caritatem, qua quilibet debet seipsum diligere. Et ideo occisio sui ipsius semper est peccatum mortale, utpote contra naturalem legem et contra caritatem existens." (Everything naturally loves itself, the result being that everything naturally keeps itself in being, and resists corruptions so far as it can. Wherefore suicide is contrary to the inclination of nature, and to charity whereby every man should love himself. Hence suicide is always a mortal sin, as being contrary to the natural law and to charity.) - Thomas Aquinas, Summa Theologica, II - IIae, q. 64, a. 5.

${ }^{28}$ Aristotle, Nicomachean Ethics, V/15, 1138a.

29 "Quilibet autem homo est pars communitatis, et ita id quod est, est communitatis. Unde in hoc quod seipsum interficit, iniuriam communitati facit." - Thomas Aquinas, Summa Theologica, II - IIae, q. 64, a. 5. 30 "... quia vita est quoddam donum divinitus homini attributum, et eius potestati subiectum qui occidit et vivere facit. Et ideo qui seipsum vita privat in Deum peccat, sicut qui alienum servum interficit peccat in dominum cuius est servus; et sicut peccat ille qui usurpat sibi iudicium de re sibi non commissa. Ad solum enim Deum pertinet iudicium mortis et vitae." (Life is God's gift to human beings; life is subject to God's power, only God kills and makes to live. So whoever takes his own life, sins against God, even as the one who kills another's slave, sins against that slave's master, and as the one who usurps to himself judgment of a matter not entrusted to him. For it belongs to God alone to pronounce sentence of death and life.) - Thomas Aquinas, Summa Theologica, II - IIae, q. 64, a. 5, ad 3.
} 
space and time) and the church punishment of "excommunication" applied, which included burial extra murales, (out of the Christian cemetery), the suicide would then be punished by God with the committer excluded from heaven (out of space and time). ${ }^{31}$ From such criminalization of suicide, moral rigorousness and intransigence follows and hence the religious and social abhorrence of suicide characteristic of a large part of historical Christianity. One should add that to some extent, this form of moral terrorism still survives, albeit a Christian burial has been allowed for several decades now. This historical context has been mentioned because there are people even today (and not as very rare exceptions) who think in a very similar way as the very late medieval theologians.

Paradoxically, within Aquinas' argumentation, contemporary involuntary euthanasia would be more justifiable than voluntary (active) euthanasia. For instance, the case of someone being sentenced to death for the good of society but who will receive a milder post-mortal punishment, contrasted to the suicide victim, who might deserve a "good death", but by virtue of his/her "sin", is condemned to the worst of all possible afterlives. 32 The death penalty, avoiding a bigger "eternal punishment", does not offend all beings, as much as voluntary euthanasia does. Then such involuntary "good death", in the form of the death penalty, would be more compatible with the norm "You shall not kill" where exceptions such as "a just war" or "capital punishment" exist, than voluntary euthanasia, which assumes that the person requesting death freely would affront each and all. Within the Thomist framework, based on Aquinas theology, mercy related to death would take the form of the "mercy killing" of a serious criminal. This version of Christian theology does not have the same mercy with a human being suffering in a devastating and possibly unbearable way.

Similar to Antiquity, with multiple viewpoints on what constituted a "good death", the Middle Ages also held another view, one which was neither rapid nor painless, namely foreseen death: death which is expected in harmony with the following wisdom: mors certa hora incerta (death being certain, but with an uncertain hour of arrival). Such death finds one waiting and expectant, ready to "go". Such an expected death is peaceful because it has been accepted with equanimity. This emphasis on "good death" as a lifelong activity and continuously expected event, supported and potentiated by Christian Platonism and by the ethics of Stoa and adopted by Christianity (but "rid of" autothanatos) has markedly transformed the biblical message and this can be found in the Christianity of nowadays. In this approach the soul is in the body as if in a prison, all throughout life awaiting the moment of liberation, which coincides with death. There is a reciprocity of arts: the art of living well corresponds to the art of dying well (ars vivendi - art moriendi). Thus the art of dying (ars moriendi) is part of the concept of "good death".

\footnotetext{
${ }^{31}$ The theological penalization ("eternal damnation") was followed by a secular penalization which spread extensively in the period from the $16^{\text {th }}$ to $18^{\text {th }}$ century. The medieval argumentation against suicide gained a simplified form: As suicide is a crime against God, against society, and against natural law, it is so against the king as well. Therefore it was up to the king (monarch) to introduce punishment for the crime committed against his majesty in the case of suicide. So suicide became a crime of great castigation such as the confiscation of the suicide's property. It took a long time to revoke this crime of suicide. For instance in England, the penalty for suicide was suspended in 1823 with suicide ultimately decriminalized in 1961 (Markson, 1969).

${ }^{32}$ Cf. Thomas Aquinas, Summa Theologica, II - IIae, q. 25, a. 6, ad 2.
} 
While suicide was treated by the medieval authors mainly in abstract theological categories (and as a morally forbidden item), in the Renaissance attention in the evaluation of suicide shifted to empirical categories and to the situation of the individual suicide. The metaphysical psychology was replaced by an empirical one. As a result, it was determined that suicide is not the worst thing under the Sun and the morality of suicide was assessed differently from the model "sin against all". Further developments in the understanding of suicide came with the Reformation ${ }^{33}$ and the Age of Reason.

\subsection{The modern era}

From the era of the Renaissance one particular thinker is worthy of mention in the context of euthanasia, namely the humanist Thomas More (1478-1535). In his Utopia (1516), he proposed euthanasia as an option for hopelessly sick patients. His concept of euthanasia is different from that used in Antiquity (and later by Francis Bacon) where euthanasia means a peaceful nonviolent death. For Thomas More, euthanasia was a kind of last option for patients without any hope of cure. Euthanasia was for the Lord Chancellor, also known as Saint Thomas More, a compassionate answer to human suffering and tragedy. Besides medical hopelessness, there were two other conditions for euthanasia. First, euthanasia has to be a "voluntarily death", chosen by a person "with a torturing and lingering pain" 34 ; a request for euthanasia can only be accepted in medically desperate situations where nothing has been left undone that can contribute to health ("they use all possible ways to cherish them and to make their lives as comfortable as possible"35). No one can be forced to ask for euthanasia, similarly no one can be killed against his/her will. It is regarded as legitimate to "choose rather to die since they cannot live in much misery"36. Persons in such misery are exhorted by priests and by magistrates, that, "since they are now unable to go on with the business of life, are become a burden to themselves and to all about them, and they have really out-lived themselves, they should no longer nourish such a rooted distemper" 37 . They can be persuaded to end their life but "if they cannot be persuaded to it, this does not induce them to fail in their attendance and care of them." 38 The second condition concerns approval by public authorities, both civil and religious. Then a death chosen voluntarily and "upon such an authority" 39 is deemed very honourable. Failing in this public approval means violation. ${ }^{40}$ More's concept of euthanasia includes both (assisted) suicide ${ }^{41}$ and intentional

\footnotetext{
${ }^{33}$ Within the Reformation tradition, since approximately the 1930s, the intellectual streams which admit euthanasia as an act of mercy (mercy killing) have won recognition; clergy of diverse confessions played an important role in establishing associations which supported euthanasia. One of the most prominent proponents of euthanasia understood as mercy killing was (originally Episcopalian minister) Joseph F. Fletcher (1905-1991) - see Fletcher, 1954, 1979.

${ }^{34}$ More, T. (2011). Utopia. Available at http://www.gutenberg.org/. Cited 20.03.2011.

${ }^{35}$ Ibidem.

${ }^{36}$ Ibidem.

37 Ibidem.

${ }^{38}$ Ibidem.

${ }^{39}$ Ibidem.

40 "If any man takes away his own life without the approbation of the priests and the senate, they give him none of the honours of a decent funeral, but throw his body into a ditch." (More, 2011).

${ }_{41}$ "They starve themselves of their own accord, or take opium, and by that means die without pain." Ibidem.
} 
killing. ${ }^{42}$ More believed that his concept of voluntary and involuntary death is legitimate: "They think they behave not only reasonably but in a manner consistent with religion and piety; because they follow the advice given them by their priests, who are the expounders of the will of God." 43 Fortunately enough for him the concept of euthanasia was a utopian concept appropriate for the best state in the new island Utopia. ${ }^{44}$ (How could More be canonized today as a public supporter of euthanasia?) Utopia literary means no-place, however More in the context of the English pronunciation of the word "utopia" is transforming "utopia" into "eutopia" (good place), a place of felicity. ${ }^{45}$ This concept of euthanasia inspired praxis of euthanasia in England in the $16^{\text {th }}$ century (Graziani, 1969). It is difficult to extrapolate to what extent More would apply his euthanasia (with the semantics he used) - limited to fiction solely or into the real world of current biomedicine. One can guess that his esteem for autonomy, mercy and public approval would lead him to be supportive of active voluntary euthanasia.

One of the first modern thinkers who significantly influenced later conceptions of science and scientific knowledge (scientia est potentia) ${ }^{46}$ and who came out with a new concept of euthanasia was the English late Renaissance philosopher Francis Bacon (1561-1626). His new understanding of science indirectly affected medicine as well: medicine should include both science and art, which enables a physician to help the patient to die in an easy and natural way. According to Bacon, medicine should include both scientific knowledge and practical skills that enable physicians to help their patients die an easy and peaceful death. When describing this medical art, he uses the term "euthanasia exteriori" 47 (a good death coming from outside) (Bacon, 2000). Simultaneously a good death should come from inside (euthanasia interiori) in a form of a sweet and calm dying while the soul of the patient is being prepared (caring for the dying). Apparently Bacon makes use of the term "euthanasia" in the context used by Suetonius when he reported the death of the emperor Augustus. ${ }^{48}$ By euthanasia Bacon means the quiet peaceful death of a person who is expecting it. The sense of euthanasia is for him to die non-violently and painlessly, falling asleep. Sleep is to him, similarly to the ancient understanding, a metaphor for death. ${ }^{49}$ To aid such a peaceful death is an important task of medicine. The physician's role is to

\footnotetext{
42 "... being assured that if they thus deliver themselves from torture, or are willing that others should do it." - Ibidem.

${ }^{43}$ Ibidem.

${ }^{44}$ The full and original title of the book is "Libellus vere aureus, nec minus salutaris quam festivus, de optimo rei publicae statu deque nova insula Utopia".

${ }^{45}$ In the addendum to his book, More proposed to change the semantics and to transform "utopia" to

"eutopia": "Wherfore not Utopia, but rather rightely my name is Eutopia, a place of felicity".

${ }^{46}$ This aphorism can already be found in Bacon's work Meditationes sacrae (1597); nevertheless this aphorism is well known from his later work Novum organum (1620) where it established what is known today as the Baconian paradigm.

${ }^{47}$ The original title of the work where Bacon deals with the medical art of "euthanasia exteriori" is $O f$ the proficience and aduancement of learning, diuine and humane (English titled, written in Latin, published in London in 1605 by H. Tomes). Recently published under the title The advancement of learning (Oxford University Press, 2000).

48 Of the Proficience and Advancement of learning, divine and humane, Book I, X/7.

49 If Francis Bacon would have been writing his "Advancement of learning" today, he probably would include a passage about terminal sedation as a specific type of medical art that helps the patient to asleep/die peacefully.
} 
accompany the patient in dying a painless and equable death.50 Bacon harmonized the medical good death in its ancient meaning (peaceful death) with the medieval concept of the ars moriendi and with care of the dying persons that we would refer to today as palliative care. Bacon's concept of euthanasia as medical help in natural dying was the leading concept of euthanasia for medical practice until the $19^{\text {th }}$ century.

The development of views about euthanasia has been strongly influenced by social progress in opinions about suicide. Since the $16^{\text {th }}$ century, within the mainstream opinion which held suicide as morally unacceptable, singular voices started to appear which held suicide as morally legitimate and justifiable in cases of serious illness. This meant a breach of the erstwhile dominant moral doctrine of Christianity. To this minority opinion belong the ideas of the French Renaissance philosopher Michel de Montaigne (1533-1592). De Montaigne claimed that God allows man to take life, if man is facing conditions under which it is worse to live then to die (de Montaigne, 1946, p. 338). Within such a statement, the ancient concept of good death which was held by the Stoics in particular can be found; if someone finds oneself in a situation of enormous suffering, then it corresponds more to human dignity and nobility to abandon such a situation, even if the price of departure entails one's own life. De Montaigne, using the logic of the Stoics, provides a religious justification: in such a case, God does not oblige one to stay in such a situation at whatever the cost, instead allowing the person the possibility of choice; if one wants he/she is allowed to depart honestly, even at the price of his/her own (not another's) life. His writings were very influential, being read by Shakespeare, Rousseau, Pascal, Emerson and Nietzsche.

The Enlightenment, with its criticism, secularism and individualism, was a very powerful milestone in the development of opinions about suicide. Probably the most significant contribution of this period to the discussion of suicide comes from Hume's aptly named essay On Suicide (published posthumously in 1783), which remains one of the most influential philosophical treatments of suicide in modern times. In this work, David Hume (1711-1776) criticises superstition and "false religion" (Hume, 1985, p. 579) which forces humans to prolong a "miserable existence" in order not to offend God. ${ }^{51}$ Hume turns the argument of the injustice induced to society by suicide around (Aristotle, Aquinas): the miserable existence is a burden for society, therefore an individual who chooses to exit from life in such a situation, provides benefit to society and his/her act is not condemnable but commendable.52 "A man, who retires from life, does no harm to society. He only ceases to do good, which, if it be an injury, is of the lowest kind" (Hume, 1985, p. 586). Suicide can be in harmony with the interest of the individual and with his/her commitment to him/her

\footnotetext{
50 "But the physicians contrariwise do make a kind of scruple and religion to stay with the patient after the disease is deplored; whereas in my judgment they ought both to inquire the skill, and to give the attendances, for the facilitating and assuaging of the pains and agonies of death." (Bacon, F. Of the Proficience and Advancement of learning, divine and humane, Book I, X/7).

51 “...death alone can put a full period to his misery, he dares not fly to this refuge, but still prolongs a miserable existence from a vain fear left he offend his Maker, by using the power, with which that beneficent being has endowed him." (Hume, 1985, p. 583).

52 "...suppose, that it is no longer in my power to promote the interest of the public: Suppose, that I am a burthen to it: Suppose, that my life hinders some person from being much more useful to the public. In such cases my resignation of life must not only be innocent but laudable. And most people, who lie under any temptation to abandon existence, are in some such situation. Those, who have health, or power, or authority, have commonly better reason to be in humour with the world."- Hume, D. (1985, p. 587).
} 
self. According to Hume, it is doubtless that the hardship of old age, suffering from illness or misery of fate can be even worse than annihilation caused by suicide. 53 This argument certainly plays a role in the contemporary discussions of the morality of assisted suicide in a medical context. (Frey, 1999). For Hume, there are calamities of life, against which it is necessary to employ suicide as the fatal remedy. Hume is convinced that immense suffering and the wish to die can be understood as a challenge and invitation by which is one recalled from life. Hume, in concord with the ancient tradition, declares that suffering which does not have any positive social contribution, being in fact a burden, does not constitute any duty to prolong such life. Furthermore everybody has "native liberty" in which he/she arranges his/her own life. The same liberty provides the opportunity to shape a happy life ("chance for happiness in life"). ${ }^{4}$ Hume argues that suicide is no transgression of duty to God and everybody has the free disposal of their own life. Moreover, when pain and sorrow overcome the patience of a person and when consequently one is tired of life, it is a clear sign ("the clearest and most express terms") that the person is recalled from the station, from life (Hume, 1985). To accept a voluntary death is equal to receiving death "from the hands of the Deity as if it had proceeded from a lion, a precipice, or a fever." In line with some Classical authors, Hume thinks that there are many more things other than disease that can render life a burden. In such conditions he also considers suicide as a noble reaction to life: "If it be no crime, both prudence and courage should engage us to rid ourselves at once of existence, when it becomes a burthen." (Hume, 1985, p. 588).55

An antipode to Hume's approach to suicide is that of Immanuel Kant (1724-1804). Kant criticises suicide heavily. His main argument against suicide stems from the Categorical Imperative: suicide cannot become a principle of universal legislation, being contrary to the natural law. The Categorical Imperative is for Kant the basic principle that is intrinsically valid, being good in and of itself and as such it must be obeyed by all and in all situations, without exception. This general imperative as an unconditional moral duty says that one has to act in a way that the maxim of his/her will can at the same time serve as the universal natural law, anytime manifesting the universal law through the maxims of the acting person. So the fundamental obligation is to follow the maxims. ${ }^{56}$ Then he immediately gives suicide as the first example of a duty toward oneself, concluding that by committing suicide, one would be completely inconsistent with the supreme principle of all duty. ${ }^{57}$ Similarly in

\footnotetext{
53 "That Suicide may often be consistent with interest, and with our duty to ourselves, no one can question who allows, that age, sickness, or misfortune may render life a burthen, and make it worse even than annihilation" (Hume, 1985, p. 588).

${ }^{54}$ Hume (1985, p. 588).

55 "This is the only way, that we can then be useful to society, by setting an example, which, if imitated, would preserve to every one his chance for happiness in life, and would effectually free him from all danger of misery." (Hume, 1985, p. 588).

56 "Handle so, als ob die Maxime deiner Handlung durch deinen Willen zum ALLGEMEINEN

NATURGETZE werden sollte." Kant, I. (1996). Grundlegung zur Metaphysik der Sitten, p. 68.

57 "A man reduced to despair by a series of misfortunes feels wearied of life, but is still so far in possession of his reason that he can ask himself whether it would not be contrary to his duty to himself to take his own life. Now he inquires whether the maxim of his action could become a universal law of nature. His maxim is: 'From self-love I adopt it as a principle to shorten my life when its longer duration is likely to bring more evil than satisfaction.' It is asked then simply whether this principle founded on self-love can become a universal law of nature. Now we see at once that a system of nature of which it should be a law to destroy life by means of the very feeling whose special nature it is to impel to the
} 
the context of the Categorical Imperative formulated by ends (German Zweck), Kant again as a first example mentions suicide. 58 "He who contemplates suicide should ask himself whether his action can be consistent with the idea of humanity as an end in itself. If he destroys himself in order to escape from painful circumstances, he uses a person merely as a means to maintain a tolerable condition up to the end of life. But a man is not a thing, that is to say, something which can be used merely as means, but must be in all his actions always considered as an end in himself. I cannot, therefore, dispose in any way of a man in my own person so as to mutilate him, to damage or kill him." 59 So suicide is a discrepancy to the idea of humanity understood as the human being both as an individual and as the whole of mankind as an end in itself (German Zweck an sich). One is not allowed to dispose of one's own life in the sense of its termination. Everyone has a duty to maintain one's own life, and, according to Kant, everyone also has a direct inclination to do so (Kant, 1996, p. 80). Kant's argumentation takes the approach that suicide as a violation of the duty towards oneself in the religious sense and therefore against God.60 So his argumentation is in line with the religiously justified prohibition of suicide.

To provide an overview on philosophical approaches to death in the modern and postmodern period is beyond this study. However it is necessary to introduce one very influential author, namely Friedrich Nietzsche (1844-1900). Concerning suicide, Nietzsche held a position very similar to that of Hume: man is an autonomous being which has the capacity and moral right to terminate his/her own life which has become unbearable and worthless. Such an act is positive both for society and for the individual, in particular if it is done as the consequence of illness, suffering or misfortune when such an individual is not useful for society, instead being a burden on society. Nietzsche formulated the new idea about free death (frei zum Tode und frei im Tode); $; 1$ his leading idea being "Stirb zur rechten Zeit (die at the right moment) (Nietzsche, 1997, p. 35). He goes further than the Stoics did. For the Stoics it was an act of honesty and moral integrity to commit suicide under conditions of extreme hardship (serious illness, misfortune) or as a preventive measure in order not to be dishonoured (e.g. soldiers). For Nietzsche the "indication list" for suicide is broader; one has to determine the proper moment of death: to die in the right moment, to die when I want.62 Many of Nietzsche's thoughts have inspired contemporary euthanasia: euthanasia is a free death. A good death is not only a desired and freely chosen one but also a quick death. ${ }^{63}$ In Zarathustra, the desire for death (Sehnsucht zum Tode) appears; so one can

improvement of life would contradict itself and, therefore, could not exist as a system of nature; hence that maxim cannot possibly exist as a universal law of nature and, consequently, would be wholly inconsistent with the supreme principle of all duty." - Kant, I. Fundamental Principles of the Metaphysic of Morals. Available at http:/ / www.gutenberg.org/. Cited 20.03.2011. (Kant, 1996, p. 69). 58 "Handle so, dass du die Menschheit sowohl in deiner Person, als in der Person eines jeden anderen jederzeit zugleich als Zweck, niemals bloß als Mittel brauchst" (Kant, 1996, p. 79).

${ }^{59}$ Kant, I. Fundamental Principles of the Metaphysic of Morals. Available at http://www.gutenberg.org/. Cited 20.03.2011.

${ }^{60}$ Cf. Kant, I. (1990). Die Metaphysik der Sitten, pp. 327-334.

${ }^{61}$ Nietzsche, F. (1997). Also Sprach Zarathustra. In: Werke, Vol. II, p. 36 (Essen: Phaidon).

62 "Meinen Tod lobe ich euch, den freien Tod, der mir kommt, weil ich will." (Nietzsche, 1997, p. 35)

${ }_{63}$ "Möchten Prediger kommen des schnellen Todes! Das wären mir die rechten Stürme und Schüttler an Lebensbäumen! Aber ich höre nur den langsamen Tod predigen und Geduld mit allem 'Irdischen'."

(Nietzsche, 1997, p. 36) 
say that with regard to Nietzsche's leading idea, a good death is the desired death. For Nietzsche, the human being is something that has to be overcome. ${ }^{64}$ When man dies there is the possibility that the Superhuman (Übermensch) can live (Nietzsche, 1997). Thus death can be regarded as doom and as a transition. 65 The fascinating aspect of Nietzsche's thinking, concepts of extinction, doom, disappearance and "twilight", expressed by the term Untergang and within the context of death, has to be contemplated. Consequently, according to Nietzsche, my I has to disappear, my I has to be overcome and death is the closest, most logical and natural way how my I can be overcome in space and time. ${ }^{66}$ Finally there is a correlation in Nietzsche's thoughts between life and heaviness: life is a weight that is borne. ${ }^{67}$ Moreover, if one thinks of a very difficult situation in life such as disseminated carcinoma, more validity would be given to this statement. So it is not only the programmatic pessimism of Nietzsche's world (Geist der Schwere) but also the desperateness of various situations in life which make the heaviness and onerousness of life even that much more a burden.

Finally, in passing from the modern thinkers to the medical practice of the $20^{\text {th }}$ century, Charles Darwin (1809-1892), the author of evolutionary theory needs to be mentioned. Evolutionary theory at the end of the 19th century had become a key concept for the natural and social sciences; applied to biology and sociology it gave rise to sociobiology, a very influential stream within the scientific community at the turn of the $20^{\text {th }}$ century. Evolutionary theory brought new approaches to society such as concepts of development and progress, and how to deal with the problem of weak individuals, incurable patients and the handicapped accordingly. As the progress of society depends on strong individuals with appropriate features and the natural selection mechanism is the driving force of evolution, which in order to ascend further and further has to rid itself of everything that hampers this process, it was viewed that only those strong enough and properly equipped would be able to continue the evolutionary process. Contrariwise evolution frees itself of those who are weak, infirm and manifestly unfit. This evolutionary theory has been both used and abused by medicine - for instance within eugenic movements. In difference to the Kantian maxim (human being as the end in itself), within evolutionary approaches this anthropological and ethical premise has been replaced by an evolutionary maxim: evolution is the goal and the individual is a means to achieve this goal. This brings back Nietzsche's words about humans having to be overcome by the Superhuman. Both Nietzsche's philosophy and Darwinism in its reduced form contributed to the later concept of euthanasia (both as social and eugenic euthanasia) of the $19^{\text {th }}$ and $20^{\text {th }}$ century. Darwinians directly affected views on euthanasia, justifying euthanasia as a form of physician-induced painless death for "degenerates", "cripples" and other "unfit" persons and arguing that the doctrine of evolution justifies shortening the lives of suffering people (Vanderpool, 2004).

\section{Euthanasia and medicine in the $19^{\text {th }}$ and $20^{\text {th }}$ century}

Within a history of the meanings of euthanasia, not only philosophical concepts - which as an integral part of the Western cultural heritage have been influencing social attitudes and

\footnotetext{
64 “Der Mensch ist etwas, das überwunden werden soll” (Nietzsche, 1997, p. 9).

65 “Was groß ist am Menschen, das ist, daß er eine Brücke und kein Zweck ist, [...] daß er ein Übergang und ein Untergang ist" (Nietzsche, 1997, p. 10).

66 "Mein Ich ist Etwas, das überwunden werden soll" (Nietzsche, 1997, p. 20).

67 “Ja, das Leben ist schwer zu tragen!" (Nietzsche, 1997, p. 87).
} 
medical approaches to life and to the ending of human life - have to be introduced but also the changing modes of medical practice. These modes, which have also influenced the beliefs and actions of physicians and the social perceptions of issues such as eugenics, medical advancement or "death and dying" movements have to be taken into account.

\subsection{Euthanasia and the medical practice to 187068}

For centuries, the goal of medicine was to soften the symptoms of disease, to save and to preserve human life. From the beginning of the $17^{\text {th }}$ century, euthanasia was understood as a science and art to soothe suffering, to accompany the dying patient and to help one to die easily and naturally. In this context, euthanasia was very similar to what we call palliative care today. It belonged to this realm, one of a capacity to soften pain (even at the cost of shortening life) and provide help which would change the inevitable moment of death into one of peaceful dying. In the context of Bacon's notion of euthanasia, it was a physician's duty to soothe the last moment of life, applying "that science, called euthanasia, which checks oppressing features of illness, relieves pain, and renders the [...] inescapable hour a most peaceful one"69, as also the German physician Carl. F. H. Marx in 1826 exhorted his colleagues. It was also the physician's task to recognize when the hope for a cure had become exhausted and it had become necessary to accompany the patient towards a peaceful death. Similarly, it was the physician's duty with respect to the professional rules of nonmaleficence not to prolong life. To drag out life or to use life-maintaining treatment was held as inappropriate and wrong due to the harm and cruelty done to the patient. In contrast, the physician's presence at the bed of a dying patient was regarded as a physician's duty as a part of proper professional conduct. ${ }^{70}$ Euthanasia only became a subject of controversy in the late nineteenth century. However, two well-known physicians, Carl Theodor Kortum (1765-1824) and Christian Ludwig Mursinna (1744-1823) had already publicly endorsed it at the beginning of the 19th century. (Stolberg, 2008).

\subsection{Euthanasia and the medical practice from 1870 to the World War II}

The intensive development of medicine from the late $19^{\text {th }}$ century, with its increasing dependence on medical technology and institutionalization of health care, significantly affected the interpretation of good death. Since curative medicine started to exhaust more and more health care resources in terms of human resources, technical and economical means, the care for incurable and dying patients drifted out of the main focus of medical interest. Instead of the physician, it was the nurse who sat down at the bed of dying patient or this task was entrusted to clergy. Gradually physicians stopped to practise euthanasia as a way of accompanying a dying patient toward a peaceful and painless death. Furthermore, they started to apply the new possibilities of resuscitation (cardiopulmonary resuscitation in particular) to dying patients as well. A new treatment option appeared, namely the

\footnotetext{
68 The periodization proposed by Vanderpool (2004) has been adopted here. ${ }^{69}$ Marx, C.F.H. (1952). Medical Euthanasia, Journal of the History of Medicine and Allied Sciences, Vol. 7, No. 4 (April 1952), pp. 401-416. First published in Latin in 1826, English translation by W. Cane in 1952; quotation from Vanderpool (2004, p. 1425).

70 The Percival standard of medical ethics (Code of Medical Ethics, 1803), adopted by the American Medical Association (AMA) in 1847, assigned a professional duty to physicians to not abandon incurable patients and those who are dying because they deserve the physician's medical art in the easing of suffering and, in particular, the physician's human support. (Chauncey, 1975).
} 
possibility to prolong life by technical means. Such prolongation of life (and suffering), being contrary to the concept of a natural death, had been previously regarded as unacceptable; however, once technically possible, it began to be practised. (Stewart, 1918). This was further compounded by the idea of evolutionary theory based on natural selection as introduced previously in the chapter, becoming increasingly influential; with individual life losing its importance. These and other factors caused a fundamental turnaround in society's understanding of good death; a new concept of good death arose, namely euthanasia as death induced by the physician for hopelessly sick patients. An important theoretical contribution to this change was the essay by Samuel D. Williams entitled "Euthanasia", published in London in 1872. According to Williams, euthanasia is a painless death for incurably and hopelessly sick persons. He goes on to state that it is even a physician's duty to recognize such a situation and if the patient wishes so, to administrate anaesthetics which would render the patient unconscious and proceed to terminate his/her suffering by a quick and painless killing. ${ }^{71}$

A new interpretation of good death started at the beginning of the 20 $0^{\text {th }}$ century when euthanasia became a terminus technicus for the killing of undesirable and "unfit" persons, usually mentally or physically handicapped people. ${ }^{72}$ The theoretical background for euthanasia was an evolutionary approach to genetics ${ }^{73}$ which modified genetics in its application to become eugenics. Eugenics later became a tool for racial "purification". So eugenics inspired by Darwinism was transformed into eugenic euthanasia, the elimination of those who are "unfit"74 (Weikart, 2002).

\footnotetext{
${ }^{71}$ In his time, Williams' concept of euthanasia caused great excitement for its culturally non-traditional, legally questionable and medically unorthodox approach. For physicians, such an approach was held to be contrary to medical praxis (against lex artis). So until now several medical professional associations, including the World Medical Association (WMA), have repeatedly proclaimed euthanasia as contrary to medical practice. (One should add that in 1949, in the most influential International Code of Medical Ethics, the World Medical Association proclaimed that abortion is contrary to medical practice. Nevertheless, such a position is no longer held by the WMA.) - See Policies available at http://www.wma.net/. Cited 21.03.2011.

72 In 1920 in Leipzig (Germany), a slim booklet (62 pages) was published by jurist Karl Binding and psychiatrist Alfred Hoche. Its original title is "Freigabe der Vernichtung lebensunwerten Lebens: ihr Mass und ihre Form" (Unworthy life at free disposal for its annihilation: the measure and form of this annihilation). This booklet, dealing with the possibility to destroy unworthy low quality life, became the theoretical background for the subsequent eugenic euthanasia movement; in 1933 it became a manual for mass killing during the Nazi period.

${ }^{73}$ Indirect resources were used, such as the works by Francis Galton (Hereditary Genius. An Inquiry into Its Laws and Consequences, 1869; Inquiries into Human Faculty and Its Development, 1883).

${ }^{74}$ Darwin's student Ernst Haeckel (1834-1919), looking for inspiration in Antiquity, proposed that German physicians should painlessly kill physically and mentally handicapped people. As a scientific justification, he looked to evolutionary anthropology (Anthropogenie oder Entwickelungsgeschichte des Menschen. Leipzig 1874).

It should be noted that in Germany, during the Nazi era from 1933, the Law for the Prevention of Hereditarily Diseased Offspring was in force (Gesetz zur Verhütung erbkranken Nachwuchses). Based on this law, some 300000 people were involuntarily sterilized (6 000 of them died as a result of the surgery). The indications for this involuntary sterilization were "a serious physical of mental hereditary handicap: congenital dementia, schizophrenia, manic-depressive syndrome, congenital epilepsy, chorea Huntington, congenital blindness, congenital deafness, serious hereditary physical malformation, serious alcoholism".
} 
On the first of September 1939, coinciding with the outbreak of the Second World War, the Reichchancellor Adolf Hitler issued a decree ordering that a "mercy death" (Gnadentod) be provided to those "incurably sick ones". ${ }^{75}$ As a result, more than 100,000 psychiatric patients and thousands of seriously ill children were killed. This eugenics programme was euphemistically termed "euthanasia".76 Related to this "euthanasia" done by German physicians on the German population, racial euthanasia ("racial hygiene") 77 focussed on the Jewish and Roma populations continued. ${ }^{78}$

\subsection{Euthanasia and medical practice after World War II}

During World War II and in the post-war period, several techniques were developed which provided new possibilities to prolong life (for instance antibiotics, pacemakers, defibrillators, dialysis) and several new fields such as transplantation or intensive care medicine arose. Advancements in cardiology made it possible to avoid a sudden death. Gradually it became common to replace the physiological functions of individual human organs with machines. With one exception (the brain), today we are able to substitute all the organs of the human body. Among many physicians, the approach requiring that everything be done that is technically possible and practically accessible to maintain the life of the patient - or more precisely, physiological functions of the human body - prevailed. Physicians became enthralled by the scientific and technological progress of medicine, even when applying it in clinically hopeless situations, unless they were stopped by multifunctional failure, by sepsis or by a clear-headed colleague. Later, depending on the concrete cultural context, this behaviour was later upheld by the courts or by the pressure of the patient's family. As the actual practice derived from the medical goal of saving life, the following guideline was being applied: If it is not possible to cure the patient and to save life then at least extend life as long as possible (as if the longest prolonged life would be the greatest success of medicine). As a result, medicine became a victim of its own success (Krämer, 1997). Medicine's task was to battle with the enemy beyond the door (death) for as long as possible. Logically the additional suffering of both patient and his/her family was produced in a non-natural way. Death ceased to be a natural event, instead a spiteful spoiler who in the end defeats a marvellous army equipped with the latest medical technology and science. This strategy of a prolongation of life also gave rise to the question of quality of life. The call for euthanasia as a mercy death was a reaction to this technologized and dehumanizing medicine (Lock, 1996). A new concept of euthanasia came into being: A good death is a merciful death (for technology does not know mercy). In this context so called "passive euthanasia" has been discussed; this "passive euthanasia" was understood as an option with or without the patient's request not to use what has been called "extraordinary means" and by an "act of omission" (Husak, 1980; Kamm, 1994) to make it possible that a person in a terminal stage will die (McMahan, 1993). According to some people death is the

\footnotetext{
75 This one line order of Hitler's can be found in books such as that by Urban Wiesing (2004, p. 60).

76 Therefore it is understandable that in Germany the term "euthanasia" (Euthanasie) still evokes strong associations with Nazism.

77 A theoretical handbook for racial hygiene is the study by F. Lenz "Menschliche Auslese und Rassenhygiene", published 1923 in Munich (3rd edition in 1931, 593 pp.).

78 The eugenic euthanasia as it was practised during the Nazi period is only mentioned here. For more detailed account see Michalsen \& Reinhart (2006) and Vermaat (2002).
} 
only mercy in life and it would be inhuman to deny such mercy to a person in a medically desperate situation. Moreover, to produce artificial and additional suffering by technomedical means would be contrary to human rights: "No one shall be subjected to torture or to inhuman or degrading treatment or punishment." (Art. 4, European Charter of Fundamental Rights, 2000)

The act of mercy, avoiding any further suffering caused by advanced medical technology, has been discussed in the context of withholding and withdrawing treatment. Once a competent patient can decide if he/she will accept or refuse any medical treatment and once medical treatment is based on the legal provisions specified by international conventions such as the Convention for the Protection of Human Rights and Dignity of the Human Being with Regard to the Application of Biology and Medicine (Oviedo, 1997), it is obvious that a competent patient can refuse any life-saving treatment, regardless of whether it constitutes withholding or withdrawing, in a situation of medical futility. (Annas, 2005). There was (and still remains) a lot of haziness about the notion of euthanasia in this context. It is true that historically the term "passive euthanasia" has been used in this context. However I'm arguing that to use such a term today leads to new misapprehensions. Once the legal framework of advance directives (Cantor, 1993) and living wills have been established by the legislation of a particular country, it is meaningless to conclude that a person who has decided not to be treated by cardiopulmonary resuscitation or by other life supporting tools such as dialysis in terminal renal failure is requesting euthanasia!

What the post-war development of medicine has brought to the concept of good death is that of mercy killing, death upon the patient's request. (Behnke \& Bok, 1975). Similarly there were many arguments brought forth to support mercy death as a refusal of dysthanasia (retention of death) or as an active voluntary termination of life. ${ }^{79}$ As a result of these developments, a number of associations for euthanasia were born. ${ }^{80}$

The model of good death (mercy death) which arose in the $20^{\text {th }}$ century also has another manifestation in the hospice movement, with different hermeneutics of mercy. Historically it operated on a certain modification of the model of good death as it was used in the Middle Ages and in Modern Times: mercy death meaning help and support in dying. Both the hospice model of good death and the model of good death as voluntary active euthanasia appeal to a respect of the dignity of the dying person, although the interpretation of dignity can differ considerably. The meaningless prolongation of life (and the related suffering) leads not only to a reappraisal of terms such as medical futility; 81 it also challenges the notion of euthanasia as an active termination of life when the patient is physically not able to terminate his/her own life by him/her self (suicide or

\footnotetext{
${ }^{79}$ Some of these arguments are discussed in the chapter "Everything under control: How and when to die. A critical analysis of the arguments for euthanasia".

${ }^{80}$ The Voluntary Euthanasia Legislation Society (1930), The Euthanasia Society of America (1937, later Concern for Dying), Nederlandse Vereniging voor Vrijwillige Euthanasie (The Dutch Society for Voluntary Euthanasia, 1976), Deutsche Gesellschaft für humanes Sterben (German Society for Humane Dying, 1980), The World Federation of Right To Die Societies (1980) under which can be found almost all other similar societies and associations.

81 The former distinction "ordinary means" and "extraordinary means" used for a moral appraisal of medical futility, in particular by theologians, is thanks to the rapid scientific and technological development of (not only intensive) medicine completely futile: what was considered "extraordinary means" yesterday has become "ordinary means" today.
} 
assisted suicide). In the meantime useful distinctions have been established and one can discriminate between the intentional shortening of life as a by-product of the pain therapy (administration of opiates such as morphine), inducing terminal sedation, terminating of life (e.g. by administration of lethal doses of morphine) and the respectful allowance of a dying patient to die (Birnbacher, 1995; Illhardt et al. 1998; Schöne-Seifert, 1997; Spaemann \& Fuchs, 1997). To allow a dying patient to die with the medical support of palliative care and with the human support of interpersonal relationships - which is more difficult to provide than medical comfort - is probably the latest task and new goal of contemporary medicine. ${ }^{82}$ Another problem is that biological death often follows the social death of the patient.

In the period between the $17^{\text {th }}$ and $20^{\text {th }}$ century the understanding of good death underwent fundamental changes. Initially euthanasia was understood to be the active physician's support for the dying patient within a natural death. In this model euthanasia is the good (complete) care of the dying.

From approximately the 1880s, a concept of euthanasia was implemented which meant the termination of the life of a patient in a medically hopeless situation induced by the physician. In the period leading up to the World War II, euthanasia was understood as the (involuntary) killing of "unfit" people (eugenic euthanasia) which during World War II developed into racial euthanasia (the Holocaust). In the post-war period the concept of euthanasia as mercy (assisted) death arose; its two basic forms being "letting die" (to make possible a dignified dying) and "mercy killing" (killing upon request or without request). (Bishop, 2006). In contemporary discussions the focus is not on the "mercy killing" issue but on a rational and intersubjective-communicative framework for end-of-life decision-making regarding the support of human life in its final stages in an era of very technologically advanced medicine.

\section{Various historical meanings of the term 'euthanasia'}

As a summary of the previous research, the main typologies of good death as they appear through history are provided below.

1. Easy, quick and serene (natural) death.

Suetonius' description of the death of Augustus serves as an example.

This concept can be found from Antiquity to the present. However this understanding of euthanasia as a peaceful, painless and swift death is not the predominant approach in the present. Furthermore a contemporary medical death is no longer perceived as a natural death.

Used in this sense, this euthanasia is at present perceived as an ambition and yearning which does not correspond to the present day medical reality of a prolonged and technified

\footnotetext{
82 Already in 1988 the American Medical Association set the following to be a standard: “... a physician may do what is medically necessary to alleviate severe pain, or cease or omit treatment to permit a terminally ill patient whose death is imminent to die. However, he should not intentionally cause death." (AMA, 1992, p. 46). In 1987 the World Medical Association published the following: "Euthanasia, that is the act of deliberately ending the life of a patient, even at the patient's own request or at the request of close relatives, is unethical. This does not prevent the physician from respecting the desire of a patient to allow the natural process of death to follow its course in the terminal phase of sickness." Available at www.wma.net. Cited 26.03.2011.
} 
death with additional suffering. This typology of euthanasia represents rather an escape from a medico-technical death or an alternative to this medically prolonged and technically supported dying - far from a natural death.

2. Voluntary termination of life by oneself in a situation when living holds no value or death seems to be the lesser of two evils (and the option to die seems to be the lesser evil).

The classical example is suicide (autothanatos) as an expression of autonomy, control over one's life, and responsibility towards oneself and towards society.

This concept has been relevant in Antiquity (voluntary death), and in Modern Times (Nietzsche: quick and free death) including the present. (Engelhardt, 1989). This form of free autothanatos (suicide) is often understood as euthanasia in debates on assisted suicide; euthanasia in this sense is a suicide in fact, though medically assisted. In these debates, (assisted) suicide has often been semantically incorrectly replaced by euthanasia. Once replaced by euthanasia, the (medically) assisted suicide ( $A$ kills $A$ ) cannot be distinguished from euthanasia as the death of $B$ by $A$ upon the explicit request of $B$. So the term "euthanasia" used as a denotation for a peaceful and painless termination of life by means of assisted suicide is euthanasia rather in a metaphorical way.

3. Medical accompaniment of a dying person (easing pain, human support, without the possibility to prolong life).

As an example the euthanasia exteriori as proposed by Francis Bacon can be given.

This concept can be found from Antiquity until the late 19th century, being the main concept of euthanasia in the period between the $17^{\text {th }}$ and late 19th centuries.

This typology of euthanasia can be used even today as an inspiration for palliative care for seriously ill and dying patients. One of the challenges of this model of euthanasia is the rehumanization of technical medicine, well-rounded care for the dying patient and a rejection of prolonging the dying period.

4. Involuntary termination of the life of unwanted people (incurably sick, handicapped) for the good of society (secondary for the benefit of the killed person).

All cases of social euthanasia would come under this model.

This concept was influential in Antiquity; in Modern Times it has been used in the period between 1870 and 1939.

This form of euthanasia was in fact the elimination of persons suffering from serious incurable diseases and from physical or mental handicaps. Motivated and justified by mercy (mercy killing, Grandentod) this killing was a form of involuntary euthanasia, in some context even supported by law (e.g. in Germany by the Law for the Prevention of Hereditarily Diseased Offspring from the year 1933).

5. Involuntary termination of life of "unfit" people (based on genetics or race).

A specific example for this type of good death is the eugenic euthanasia as it was practiced under the Nazi regime during World War II.

This form of involuntary euthanasia was extended to genocide, resulting in the killing of millions of people (Jews and Roma primarily). Beside such racial eugenic euthanasia, medical eugenic euthanasia was also conducted during the Nazi regime; the previous more socially identifiable conditions, based on physical and mental handicaps were extended to medical indications such as schizophrenia, cyclothymia, blindness, deafness, homosexuality and many others. All these medical conditions qualified for mercy death (eugenic euthanasia). 
6. Inducing an "easy death" by sedatives (including terminal sedation) - shortening of life without direct killing, 83 foreseen but nonintended death.

This model of good death has been one of the forms of euthanasia discussed in the recent past and at present.

Once the shortening of life became a de facto side-effect of pain therapy (e.g. administration of morphine), it was discussed whether and to what extent such an abbreviation of life is morally justifiable. Some authors have argued that foreseen and non intended death caused by pain therapy (administration of high doses of morphine) is acceptable while an intended death would be morally unacceptable, justifying this assessment by the double effect doctrine. ${ }^{44}$ (Boyle, 1991; Hawryluck \& Harvey, 2000; Kamm, 1999; Klein, 2004). However, the application of the double-effect doctrine is highly problematic in this context (one has to take into account not only the real shortening of life but also the probability of death being caused by the pain killers directly). To call pain therapy which also includes the acceleration of the death factor "euthanasia" is not semantically and ethically meaningful.

7. Physician assisted suicide

Some people classify physician assisted suicide as euthanasia, subsuming suicide under euthanasia, which is confusing and out of the semantics proposed in this chapter (the killing of another person is fundamentally different from suicide).

Historically this assisted suicide has a similarity to the ancient notion of autothanatos (e.g. the Stoics), however suicide as it has been known throughout history should not be intermingled with physician assisted suicide - as we understand it today as a very specific type of suicide and fundamentally different from (unassisted) suicide - for at least two reasons: first the aid to conduct suicide is solely help, not direct perpetration; therefore the modifier "assisted" is used, second the involvement of a physician, with regard to the medical profession as such and its therapeutic role, is of a specific moral relevance; this aspect is evoked by the modifier "physician". (Deigh, 1998; van der Maas, 1996; Wolf, 2008). Should a clear semantical framework be used for euthanasia discussions, then physician assisted suicide has to be distinguished from euthanasia, and not subsumed under euthanasia. While in euthanasia the physician is the perpetrator of death, in physician assisted suicide it is the patient who causes death.

8. No application of medically futile therapy which prolongs the life (and suffering) of the terminally ill patient: withholding life-sustaining treatment

The typical situation is one of withholding life-sustaining treatment with or without the patient's consent because the treatment would be medically futile for that patient.

Some people consider the withholding of medically futile treatment as "passive" euthanasia while others do not call withholding of treatment "euthanasia" at all. If the withholding of

\footnotetext{
83 The fear of an abridgment of life (even that of a dying patient) is understandable, since such a shortening of life is in contrast to the general tendency to prolong life. However, such fear should be contextualized in the situation of a terminally ill and dying patient, where pain therapy (opiates) which alleviate suffering, and support dignity in dying but often shorten the life of the patient- is arguable necessary.

84 The doctrine of double effect, having been developed and applied to end-of-life decision making chiefly by various Catholic theologians as an authoritative tool for assessment of moral acceptability within moral absolutism, has been intensively criticized and refuted by many authors (Donagan, 1991; Kamm, 1991; Quill, 1997). It seems to be very helpful in contemporary debates focused on the shortening of life as a side-effect of pain therapy and in the context of euthanasia.
} 
futile treatment, thus hastening the dying process, is held as euthanasia (even as "passive" euthanasia and therefore "not so bad" as the "active" one), then the withholding of medically futile treatment is morally wrong because such an act would be equated with ("passive") euthanasia. Then two completely different notions of euthanasia have been applied in the form of a "good one" namely "passive" euthanasia (withholding, letting die) and a "bad one" namely "active" euthanasia (active killing). Thus two completely different situations have been denominated by one and the same term, then we have situations were euthanasia is "good" and "permissible" and situations where euthanasia is "evil" and "wrong". In the end we have deeply confusing semantics which causes that euthanasia discussions will be meaningless.

9. Termination of medically futile therapy which prolongs life (and suffering) of the terminally ill patient: withdrawing life-sustaining treatment

This type of "euthanasia" coincides with withdrawing of medically futile therapy (including life-sustaining treatment) with or without the patient's consent.

Some people hold the withdrawing of medically futile treatment as "passive“ euthanasia while other people do not subsume the withdrawing of life-sustaining treatment in a situation of medical futility under euthanasia, arguing that euthanasia in the proper sense can be active (voluntary) only.

Assuming that both killing and letting die are morally wrong, then any therapy (treatment) which has been started has to continue until the death of the patient because it would be morally wrong to withdraw (any) treatment. Then the morally right approach would be "to cure until death" and to put the patient under medically conducted torture. The only prevention of such a medically generated ordeal would be the patient's timely refusal or late court decision.

In conclusion both the withholding and withdrawing of medically futile treatment shall not be called euthanasia (even if it is considered "passive").

10. Painless termination of life of an unbearably suffering patient by the physician upon the patient's request.

This model is called voluntary (active) euthanasia, ${ }^{85}$ meaning that a clearly competent patient makes a voluntary and continuous request for death and the physician conducts the act of euthanasia (killing by medical means). This type of euthanasia is legally permitted in the Netherlands, Belgium and Luxemburg. Within this typology, euthanasia, being clearly defined with specifying conditions (the Rotterdam criteria), can be called the "Dutch model" of euthanasia.

It is obvious that unbearable suffering is too subjective (only the suffering person can decide if the suffering is "unbearable") and to difficult to be grasped and objectified. The criterion "unbearable suffering" does not seem to be in accordance with our objective (evidence based) medicine. Moreover this criterion could also qualify psychiatric patients (especially those suffering from depression) and somatically healthy persons suffering from "tired of life" and other states of existential suffering such as meaningless and pointlessness to request death.

11. Painless termination of life of a terminally ill patient (terminal stage of life) by a physician upon the patient's request.

\footnotetext{
${ }^{85}$ See the chapter "Voluntary Active Euthanasia: The Debate" by Louis-Jacques van Bogaert in this book.
} 
This model is also called voluntary (active) euthanasia. It differs from the previous one by the primary criterion: here the primary qualifying condition is terminal illness (terminal stage), in the previous model it was unbearable suffering. It should be noted that the Dutch model does not include terminal stage as a criterion for euthanasia.

Euthanasia as the painless termination of the dying patient (with or without request) is practised in the grey zone void of regulation (beside the eventual agreement between the two actors, patient and physician or relatives and physician). If conducted without the competent patient's request, such type of euthanasia belongs to the next category.

12. Painless termination of life of a terminally ill or unbearably suffering patient by the physician without the patient's request (the patient is incompetent). 86

This model, called nonvolutary euthanasia, combines two previous typologies (euthanasia in terminal stage of illness, euthanasia in unbearable suffering) with the significant difference that it is conducted without the patient's request. In this model of euthanasia one of the two criteria (terminal stage of illness or unbearable suffering) must be met and the decision to conduct euthanasia is made by the physician, without any patient's request, consent or approval (the patient is unable to give their informed consent).

13. Painless termination of life of a terminally ill or heavily suffering competent patient by the physician without patient's request or against patient's will.

This model is called involuntary euthanasia; euthanasia of a competent patient against their will. Involuntary euthanasia is a crime. Some people argue that crime does not refer to a "good" death and therefore it should be not called euthanasia.

14. (In)voluntary painless termination of life of a person other than a terminal patient.

This type of euthanasia would for instance include quadriplegic or psychiatric patients. (Sheldon, 1994).

15. (In)voluntary painless termination of life of a terminally ill or unbearably suffering person by someone other than a physician.

This type of euthanasia differs from all other conceived forms, being that of it being conducted by any other person other than a physician, ergo euthanasia by a nurse or another health care professional or by a person who does not even belong to the health care staff, e.g. a relative.

It has been stressed that semantics is a necessary starting point for any discussion on euthanasia; it is crucial to clarify what exactly is understood by the term "euthanasia" before any argument for or against will be used. It became clear that euthanasia is not an end in itself with intrinsic value but a means to realize the end of a good death, or more precisely, a quality dying experience. (Emanuel, 1999).

Among the fifteen aforementioned typologies, one in particular should be emphasised, number eleven, which seems to be the most appropriate semantic tool for the concept of euthanasia. According to this definition, euthanasia, being different from assisted suicide (Beech, 1995; Watts \& Howell, 1992) and from other scenarios of end-of-life decisions such as withholding, withdrawing or terminal sedation, is a deliberate act of termination of the life of a competent (autonomous) patient in the terminal stage of illness by a physician

\footnotetext{
${ }^{86}$ Specific attention should be given to the problem of the euthanasia of children, which would fall under typology 14 (newborn children with abnormalities) or older children under the legal age (typology 12 and 14) and to the issue of euthanasia in geriatric patients (with diminished cognitive capacities including conditions such as dementia).
} 
upon an explicit and persistent request of this patient and for his/her sake. Thus under the term "euthanasia" so called active voluntary euthanasia is understood. Should these criteria not be met, a good death can be discussed within a different framework, defined by different criteria such as involuntariness, other than terminal stage of illness (e.g. psychiatric patient), another person than the physician administrating the lethal dose, and other parameters.

\section{The meaning of euthanasia in current discussions}

In the next section, the conceptual understanding of euthanasia in current discussions will be examined. As it follows from the previous typology of euthanasia, the current debates on euthanasia are mainly based on typologies 10 through 14; some people also include typology 8 (withholding treatment) and typology 9 (withdrawing treatment) under euthanasia, under the guise of "passive euthanasia", and thereby, in a misleading way, calling the reduction or termination of medically futile treatment "euthanasia". So attention will first be given to the distinction between "passive" and "active" euthanasia.

\subsection{Euthanasia as active voluntary death}

If under the term "euthanasia" are included scenarios of withholding and withdrawing treatment, medical futility and terminal sedation, then to end medical futility or even not to start medically futile treatment is euthanasia; thus to avoid such meaningless (medically futile) treatment is euthanasia. So euthanasia is omnipresent in these end-of-life decisions. If everything is considered euthanasia then we lose our ability to correctly administer (or not) treatment. Therefore what is crucial is the art of distinguishing between treatment options while maintaining an unbiased and level semantic playing field, which allows to make the dying process as humane and as dignified as possible, without applying every kind of treatment that is technically possible, but medically futile and humanely problematic (to be rather euphemistic). That's why such care cannot be called (any form of) euthanasia!

Despite the fact that so called "passive euthanasia" has appeared in the literature and in euthanasia debates for several decades and continues to appear in both the literature and in public debates - one can understand when, why, and under which circumstances this term was developed - but if euthanasia is understood as the killing of $B$ by $A$ upon an explicit request of $B$, then the term "passive euthanasia" remains semantic nonsense and a source of many misunderstandings, emotions and frustration. What has been called "passive euthanasia" ( $A$ allows $B$ to die without undertaking all technically possible but medically futile steps) should rather be called "letting die" or "allowing to die" since the life of the dying person cannot be saved. This "allowing to die" is in line with the respect for human dignity and could be labelled as a "good death" but not as "euthanasia" is the sense described above. The former distinction "active" and "passive" euthanasia aimed to distinguish morally acceptable "passive euthanasia" as a form of non-obligatory passivity (omission), which did not apply so-called "extraordinary means" which had been previously regarded as morally obligatory to use, from morally unacceptable "active euthanasia" consisting of killing a person (homicide). ${ }^{87}$

\footnotetext{
${ }^{87}$ In the late 1960s and early 1970s both bioethicists and national medical associations started to approve, under specified conditions, "of some kinds of instances of what is called 'passive' euthanasia"
} 
The cessation of the employment of extraordinary means to prolong life when there is irrefutable evidence that death is imminent is the decision made primarily by the patient and/or by the family and/or by physicians. But such a decision and such cessation of medical treatment is very different from what is at present considered "euthanasia". The doctrine establishing an important moral difference between "commission" and "omission", between "active" and "passive", between "ordinary means" and "extraordinary means" became useless and misleading when applied to euthanasia as it was understood in the 1970s and 1980s (Husak, 1980; Jonsen, 1998; Kamm, 1994; Walton, 1976). It follows that in one case, euthanasia is sometimes permissible, while in another case always forbidden. This doctrine, based on the distinction between act (commission) and omission, and adopted by the American Medical Association in 1973, was very soon challenged, as this would lead to decisions on life and death being made on morally irrelevant grounds (Rachels, 1975), at present not recognized by most philosophers. Moreover, active euthanasia (the "bad" one) would be in many cases more humane than passive euthanasia (the "permissible" one). So later, when medical associations issued guidelines for withholding and withdrawing treatment and for palliative and terminal sedation, they often stressed that this policy is not identical with active euthanasia, without declaring that they are authorizing "passive" euthanasia.

From the present perspective, the former distinction of "active" and "passive" euthanasia as established in the 1970s, with the aim of helping physicians adapt to the new situations they were finding themselves in and to move from a curative paradigm to a palliative paradigm (the shift from "cure" to "care") and to provide a moral rationale for the dignified treatment of terminally ill patients is a good illustration of the changes taking place and serves as an appropriate departure point to clarify terminology and then to discuss ethics. At the beginning of the $21^{\text {st }}$ century, not only philosophers but physicians from palliative care units have argued that so-called "passive euthanasia" is a contradiction in terms, reasoning that palliative care which saves the dying patient from extreme pain, protects human dignity

because there was an acute need for some regulatory tools for the newly arisen "very pressing, widespread problems introduced by recent developments in medical technology"(Walton, 1976, p. 343). So in the case "of a terminally ill patient, who is in great pain and who is known to be about to die with overwhelming probability in a few days or a few hours, and shows symptoms of immediately imminent death" a new medical paradigm emerged, namely the option not to use all medical technology currently available to prolong life. As part of this new medical paradigm, the ideas such as "not to prolong the patient's life for a short and excruciatingly painful time" and not to use the available "active emergency methods of resuscitation" (e.g., defibrillators or heart massage) and not to "do what would constitute extreme cruelty" asserted themselves. (Walton, 1976, p. 343). Douglas Walton summarizes the debates of that time in the following way: "What is the physician to do? It has seemed to many that heroic measures should, under certain conditions, be waived. But does not such a waiver constitute 'killing' the patient? On the other side, is not a too-strenuous interference in the course of nature equally morally abhorrent, cruel, and inhumane? The latter course may not seem to serve the interests of the patient, if unthinkingly or automatically always applied." (Walton, 1976, p. 343) As a possible basis for resolving these problems the distinction "active" and "passive" euthanasia has been often cited. "The former entails active interference in the course of natural events, the taking of steps through positive action. Passive euthanasia carries with it no such requirement but only failure to institute positive action, letting nature take its course, so to speak. Thus it is sometimes felt that passive euthanasia is morally acceptable, under certain conditions, but that active euthanasia is never morally acceptable under any conditions." (Walton, 1976, p. 343). 
and the patient from additional suffering and medical torture does not amount to euthanasia (Riley et at., 2009). The European Association of Palliative Care consistently refuses to call any of the following clinical procedures euthanasia: withholding futile treatment, withdrawing futile treatment or terminal sedation, emphasizing that euthanasia can be active in nature only (Materstvedt, 2003, p. 98).

In my judgement to use the term "euthanasia" within palliative care provided lege artis is an expression of disrespect and a violation of the efforts of palliative medicine and the health care staff who accompany the dying persons, alleviating pain, providing both human and medical comfort in dying. Naturally they cannot agree to such human support being called euthanasia, using the same word as "mercy killing" does. There is a huge difference in the "good death" of palliative care: the patient dies due to the disease, not to the physician or attending personnel who kill the dying (terminally ill) patient (Callahan, 1999).

Fortunately enough the distinction "active" and "passive" euthanasia has gradually been abandoned since the 1990s (Brock, 1992, 1993; Campbell et al. 2005; McLachlan, 2008; Warnock \& Macdonald, 2008). However, not having disappeared completely, they can still be found among some authors. When for instance John Keown defines euthanasia as "the intentional termination of life by act or omission" (Keown, 2002, p.12), he bases his concept of euthanasia on the distinction "active" and "passive", holding "omission" for "passive euthanasia". Recently Gesang (2008), insisting on the distinction "active" and "passive", has proposed specified conditions to be met so as to be considered passive euthanasia, classifying many cases as such. ${ }^{88}$ And so we are returned to "moral" and "immoral" euthanasia. Gerrard and Wilkinson (2005) examined the permissibility of so-called "passive euthanasia", emphasizing the possibility to soften the term euthanasia as a whole by including withdrawing or withholding life-prolonging treatment, as a result of their greater moral acceptance.

The important difference - not in euthanasia per se but in all acts conducted by human beings as human beings (actus hominis)- is the matter of intent, which is often confused with motive (Campbell, 2005). If euthanasia is defined as "intentional or foreseen life-shortening" (Keown, 2002, p.15), then the administration of morphine, which in addition to serving as pain therapy objectively shortens the patient's life, is euthanasia as well. If not only an intentional termination of life but also pain therapy falls under euthanasia, then it is really difficult to discuss euthanasia. In a similar vein Moody (2003) requires the critical attribute "foreseen and intended death", however as concurrent and simultaneous conditions. "It may be optimistic to expect the emergence of common definitions, at least in the near future, not least as the different definitions reflect different underlying moral presuppositions whose resolutions is a prerequisite to definitional consensus. Until such consensus is achieved participants should at least be open and clear about which definition they are employing and why." (Keown, 2002, p. 17). Obviously, one has to attempt to start a discussion with clarified semantics but it is also a matter of preconceptions that determines which definition is being used and why.

\footnotetext{
88 "Passive euthanasia occurs if the general conditions for euthanasia are fulfilled and if letting it happen leads to death. If it is a case of letting it happen leads to death only those actions may be involved that withdraw a medical measure that a doctor started previously. Every other form of euthanasia is active." (Gesang, 2008, p. 179).
} 


\subsection{Euthanasia - a core definition and the specifying criteria}

Within the conceptualization of euthanasia, the core notion of euthanasia as the primary definition and the set(s) of secondary criteria have to be distinguished. If for instance someone defines euthanasia as "the termination of life of an incurable patient" then any incurable diseases such as diabetes would qualify for a request for euthanasia. Obviously some additional specifying criteria should be applied. Or if euthanasia is described as "the active, intentional termination of life" (Keown, 2002, p. 10), then any suicide is at the same time euthanasia. Withal both the termination of life of an incurable patient and active termination of life apply for euthanasia, belonging to the essential conceptualization of euthanasia. If the definition proposed by Brock (1999, p. 298) - under which euthanasia is defined as "deliberate killing of an innocent person"- then some people, presuming that a late foetus is a person, could argue that there is little difference between euthanasia and abortion. The deficiency of such a definition is that not every "killing" is ipso facto euthanasia.

This conceptual diversity of the core definition of euthanasia has been recently shown by Quaghebeur et al. (2009). Based on this review of argument-based ethics literature, it is evident that many imprecise definitions of euthanasia can be found in the literature over the last three decades. The mentioned study demonstrates that there is a growing tendency in the preciseness and accuracy in the definition of euthanasia; while in the late 1980s and in early 1990s euthanasia was often defined as "mercy killing", "allowing to die or helping to

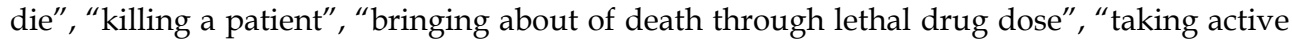
steps to end a patient's life", "an intentional, causally significant (either through omission or commission), foreseeable, and direct action undertaken for the purpose of ending life a person, for whatever reason", in the late 1990s and in 2000s more precise definitions such as "direct termination of a competent patient's life at the patient's request", "beneficent active voluntary euthanasia" and "deliberate action to terminate life by someone other than, and at the request of the patient" can be found (Quaghebeur et al., 2009). The said study also shows that more and more authors make use of the definition of euthanasia as it has been established by Dutch and Belgian legislation which defines euthanasia as "administration of lethal drugs by someone other than the person concerned with the explicit intention of ending a patient's life, at the latter's explicit request" (Belgian Ministry of Justice, 2002; Leenen, 1998; van der Heide et al., 2003, 2007; van der Wal \& Dillmann, 1994).

Within the overview of definitions provided by Quaghebeur (2009, Table 1, 2, 3) two different types of core definitions with regard to exactness can be found. One type of these essential definitions is based on "killing the patient" ("a death brought about by someone else", "purposeful shortening of human life through active or direct assistance", "killing someone at the end stages of life", "interrupt the patient's ability to sustain life", "causing the death of an innocent person", "ending the life of another person on the grounds of unworthy living"). It has been already argued that such a definition is insufficient. Another type of these essential definitions is based on "voluntary active euthanasia" ("the direct termination of a competent patient's life at the patient's request", "the intentional bringing about of person's death at their own request in the absence of coercion"). This definition based on the concept of voluntary euthanasia (voluntary euthanasia, by definition, can never be a "passive" one) is much closer to the situations which are covered by the term euthanasia. However there are some strategies which change or manipulate the concept of euthanasia. (Campbell, 1999). So for instance if the focus is on "activeness" in euthanasia as 
critique or objection to so-called "passive" euthanasia then the distinction "voluntary" and "involuntary" (resp. "non-voluntary") can be cloaked and also involuntary euthanasia can be also covered by the term "euthanasia" which is obviously contradictory to the standard definition ("termination of patient's life upon their explicit request by a physician"). Only few of the definitions based on the "voluntary active euthanasia" concept include additional criteria such as physician's activity or suffering. The lack of these secondary or additional criteria demonstrates the problem we still have with the basic understanding of euthanasia in the professional literature, not to mention the perception of the general public. If we take the "better" set of essential definitions of euthanasia, understanding euthanasia to be any medical killing upon the person's own request, then any patient is eligible to request euthanasia. At the same time such a definition is of minimal help for any euthanasia discussion.

In 1988 Michael Wreen attempted to provide an analytical definition of euthanasia. It was obvious for him that "someone must kill a live creature, or let her die, if euthanasia is to occur" (Wreen, 1988, p. 637). According to Wreen (1998), person A committed an act of euthanasia if and only if the following conditions were fulfilled:

1. $A$ killed $B$ or let her die.

2. A intended to kill $B$.

3. The intention specified in (2) was at least partial cause of the action specified in (1).

4. The causal journey from the intention specified in (2) to the action specified in (1) is more or less in accordance with $A$ 's plan of action.

5. A's killing of $B$ is a voluntary action.

6. The motive for the action specified in (1), the motive standing behind the intention specified in (2), is the good of the person killed.

7. The good specified in (6) is, or at least includes, the avoidance of evil.

This analytical definition of euthanasia, although staying within the former broad understanding of euthanasia which subsumes "letting die" as well, is more precise compared to other definitions. However, not specifying who decides about the good of $B$, this definition does not take into account the difference between voluntary and nonvoluntary (or involuntary) euthanasia, which is of crucial importance. So if groups committed to the fundamental belief that the intentional killing of another person is wrong, despite having deep sympathy for those people who are suffering, understand euthanasia as "the intentional killing by act or omission of a dependent human being for his or her alleged benefit" 89 , then a hypocrisy of "double effect" doctrine comes into play and the "lifesaving" treatment in the form of medical torture have to continue which finally reinforces the argument for active euthanasia.

Another analytical definition of euthanasia was proposed by Beauchamp and Davidson $(1979)^{90}$ which is more focused on the causality and reasoning of killing then on its volition,

\footnotetext{
89 This definition can be found at one of the leading websites dealing with euthanasia at: http://www.euthanasia.com/ definitions.html. Cited 26.03.2011.

90 "The death of a human being, A, is an instance of euthanasia if any only if (1) A's death is intended by at least one other human being, B, where B is either the cause of death or a causally relevant feature of the event resulting in death (whether by action or by omission); (2) there is either sufficient current evidence for B to believe that A is acutely suffering or irreversibly comatose, or there is sufficient current evidence related to A's present condition such that one or more known causal laws supports B's
} 
covering rather "mercy killing" by compassion than the autonomous choice of the suffering person.

Yet in 1979 Beauchamp argued that "there are two distinctions which are commonly observed in the literature on euthanasia, and we assume that any definition which could not accommodate these distinctions is incorrect" (1979, p. 299). However in 2003 he gives a less analytical and much shorter definition of euthanasia: "Euthanasia is the act or practice of ending a person's life in order to release the person from an incurable disease, intolerable suffering, or undignified death" (Beauchamp, 2003, p. 179). Instead of the distinction between "commission" and "omission" other secondary criteria are introduced (incurable disease, intolerable suffering, or undignified death) which seems to be more important than the former distinction. The rhetoric of killing and letting die is questioned (Beauchamp, 2003). However this definition, being too general, does not discriminate between voluntary and involuntary euthanasia, though Beauchamp makes use of the terms voluntary and involuntary euthanasia (2003, p. 180).

Another definition of euthanasia has been suggested by Rosemary Firth. Her definition is more narrative then analytical. Euthanasia is (a) "the medical use of drugs to ease a painful and protracted, but inevitable death", (b) "a deliberate attempt to bring about or to hasten one's own death in sickness or suffering", (c) "actively assisting an aged, sick or handicapped person to a merciful death" (Firth, 1981). These suggested interpretations of euthanasia are rather more the phenomenology of good death. Assisted suicide comes under euthanasia (c), palliative care (a) would also come under euthanasia, the shortening of life by opiates (b) would also be considered euthanasia. Such a broad description has to be made more precise. Regarding free choice on euthanasia, Philippa Foot, already in 1977 pointed out the difficulty: Even in the case of voluntary active euthanasia, "it would be hard to devise procedures that would protect people from being persuaded into giving their consent" (Foot, 1977, p. 122).

\subsection{A shift towards a more precise conceptualization of euthanasia}

Recently a certain shift in the conceptualization of euthanasia can be identified in bioethics literature. While at the end of the $20^{\text {th }}$ century a rather broad description of euthanasia was prevalent, in the $21^{\text {st }}$ century a tendency can be observed to conceptualize euthanasia in a more precise way by applying a tighter description. This shift was reflected in the change between the first and second editions of the Encyclopedia of Ethics (Becker \& Becker, 1992, 2001), which includes an article on euthanasia written by Marvin Kohl. In the first edition, Kohl (1992) tried to summarize the conceptualization of euthanasia in the following way: (a) euthanasia is "the act or method of painlessly inducing the death of a nonfetal sentient being" which distinguishes euthanasia from abortion (nonfetal sentient being), while not

belief that A will be in a condition of acute suffering or irreversibly comatoseness; (3) (a) B's primary reason for intending A's death is cessation of A's (actual or predicted) suffering or irreversible comatoseness, where $\mathrm{B}$ does not intend A's death for a different primary reason, though there may be other relevant reasons, and (b) there is sufficient current evidence for either A or B that causal means to A's death will not produce any more suffering than would be produced for A if B were not to intervene; (4) the causal means to the event of A's death are chosen by A or B to be as painless as possible, unless either $\mathrm{A}$ or $\mathrm{B}$ has an overridding reason for a more painful causal means, where the reasons for choosing the latter causal means does not conflict with the evidence in (3b); (5) A is a nonfetal organism." (Beauchamp \& Davidson, 1979, p. 304). 
distinguishing euthanasia in humans from euthanasia in animals; (b) euthanasia is "the act or method of directly causing or allowing the painless and quick death of a nonfetal being, so as to end suffering or an undesirable existence" which places "passive" euthanasia (allowing the death) under "euthanasia"; while the stated conditions (suffering, undesirable existence) remain insufficient for a suitable and applicable definition of euthanasia. Furthermore, the criterion "undesirable existence" is highly problematic since it could be interpreted to cover many diverse forms of (involuntary) euthanasia such as eugenic or social euthanasia. No distinction between euthanasia and suicide was described. Additional specific criteria would be necessary here.

It is both interesting and challenging to observe how in the second edition the same author changed his conceptualization of euthanasia: "An act of euthanasia is held to be voluntary only if there is full disclosure of relevant information to, and consent freely given by, the intended competent recipient of the act" (Kohl, 2001, p. 492). ${ }^{91}$ First he distinguishes euthanasia from suicide, establishing a specific category of physician assisted suicide. Moreover, his concern is primarily with voluntary active euthanasia, stating that "the lines between voluntary, involuntary and non-voluntary euthanasia are crucial in a society that values both self-determination and compassion" (Kohl, 2001, p. 492). This development in Kohl's conceptualization of euthanasia demonstrates the general tendency to be more specific and not to subsume any form of killing under the term "euthanasia".

Even after such a shift to a restrictive description of euthanasia, further differentiations are necessary; the following aspects in particular have to be specified:

1. The decision-making process (competent/incompetent, patient/nonpatient, patient as decision-maker, physician/family as decision-maker...)

2. Clinical conditions (terminal stage of illness, enormous suffering, medical futility...)

3. Social context (the presence or lack of human/psychological/spiritual support...)

4. Motivation and purpose (of the persons involved).

\subsection{The philosophical concepts that form the background of the euthanasia discussion}

With regard to euthanasia in contemporary technologized medicine, at least three philosophical foundations can be identified that form the background of euthanasia discussions: a teleological, deontological and human rights approach. Each in turn has its respective schools of though, traditions and movements.

The teleological approach, setting out to determine what the (good) goal would be, in the context of good death often emphasizes the quality of life concept as an important purpose of human endeavour. As a part of the quality of life, health and wellbeing, good social relations and the absence of suffering can be given. Such conceptualized human life holds a high value and is therefore inviolable. However once it heads for its inevitable end, it is an important challenge and goal to aim for a dignified ending. Then autonomy in which an individual shapes his/her own life and self-determination by which one controls the circumstances are of vital significance. Therefore, the shortening of life or termination of life (and of the related suffering) are justifiable goals worthy of acting upon and realizing.

The deontological approach mainly seeks to determine our obligations towards our life and towards the lives of others. The basic obligation towards life is to care for it, to support it,

${ }^{91}$ In 1974, Kohl defined euthanasia as "the painless inducement of a quick death" (1974, p. 94). 
and not to destroy it. Therefore suicide and euthanasia are wrong, because they violate the fundamental duty not to intentionally take life. Euthanasia thus sacrifices a person's value as a subject for the sake of his/her welfare (Luper, 2009). Since a moral obligation to terminate life cannot be positively justified, one cannot agree with the termination of life; moreover one has a duty to oppose such tendencies even against the will of the other person since the other is also bound by the duty not to take life nor to allow it to be taken. The deontological prohibition of killing is universally valid; the open question is if there are some justifiable exemptions, such as capital punishment, suicide or euthanasia.

The approach based on rights, in particular on human rights, does not identify any positive (given) or natural right to die. Therefore one cannot call for such right directly. However the right to die can be derived indirectly (e.g. from the right to life). Contrarily, the right to life belongs to human rights but one may "waive" the right to life in the case of suicide or euthanasia. Nevertheless, one is not allowed to delegate the execution of this right to another person, to allow to be legitimately killed. To take human life is morally wrong because the fundamental right to life (which is at the same time a right not to be killed) would be violated. Within liberal political philosophy, with its focus on the rights of the individual, a competent person, freely requesting the termination of his/her life which is not perceived as good and valuable anymore and having become burden to that individual, can forego his/her right to life, rendering killing as morally justifiable. In difference to the deontological approaches, within the liberal notion of rights, the duty not to be killed is limited to those who wish to live.

\section{Conclusion}

Euthanasia is a highly emotive and sensitive subject, causing disputes and misunderstandings. As many authors have pointed out, the term euthanasia, despite its frequent exposure in public media and in academic literature, does not reflect a clear set of concepts and definitions to be used in euthanasia debates. Thus, such debates often wind up inadequately formed and ineffectual, causing more frustration than solutions. It has become clear that any euthanasia discussion should be preceded by clarifications of the terminology to be used; semantics followed by ethics.

Nevertheless the concept of euthanasia is not a new topic; our interest in the issue has only been renewed due to the effects of contemporary medical technology. It has been demonstrated that both the concept of euthanasia and the euthanasia discourse have their roots in Antiquity. The diverse notions of euthanasia as they have appeared through history were described and their relevance to present day discussions was highlighted. Altogether 15 diverse notions (typologies) of euthanasia have been identified by this study. Many of them can be found in contemporary euthanasia debates.

Out of the many typologies of euthanasia, voluntary (active) euthanasia (typology 11) has been selected as the most relevant concept for the conceptualization of euthanasia to the current medical context. As the preferable concept of euthanasia the following definition was taken from this source: euthanasia is a deliberate act of terminating the life of a competent (autonomous) patient in the terminal stage of an illness, performed by a physician upon the explicit and lasting request of this patient and that patient's sake. So euthanasia, being different from both assisted suicide and physician assisted suicide, also differs from other instances of end-of-life decisions such as the withholding or withdrawing of life support or terminal sedation. 
Consequently the conceptualization of euthanasia in recent bioethics literature was examined. As one of the results, an increasing tendency to specify the notion of euthanasia using better and more homogenized semantic precision during the last few decades was identified. This has in turn been adopted more widely, resulting in our broader understanding of euthanasia being changed towards a more precise description which distinguishes between euthanasia, suicide and (physician) assisted suicide. There has been a tendency of more and more authors understanding euthanasia as voluntary (and therefore active) euthanasia. The Dutch and Belgian legal definition of euthanasia seems to have influenced the conceptualization of euthanasia in the $21^{\text {st }}$ century.

Furthermore, the most relevant philosophical approaches that form the theoretical background of stances towards euthanasia were presented (teleology, deontology, rights).

Right from the beginning, i.e. since Classical times, there has been an implicit correlation between good death and good life. Death, being not an event of life, terminates life, delimiting its boundaries as do the banks of a river. A formal determination of both good life and good death in not problematic - everybody wants a good life, including a good ending. However there is a huge discrepancy as to how to determine the content of this "good". This has led to many diverse understandings of good death existing, as the product of individual value systems and communal moralities.

One can expect that the controversy surrounding good death as an existential, emotionally sensitive and morally contentious discourse will continue to be a serious social and political challenge in this age of ever increasing medical technology, aging populations and ongoing health care debates.

\section{References}

American Medical Association (1992). Code of Medical Ethics, Current Opinions: Including the Principles of Medical Ethics, Fundamental Elements of the Patient-Physician Relationship and Rules of the Council on Ethical and Judicial Affairs, AMA Press, ISSN 15374009, Chicago, USA

Annas, G.J. (2005). The Right to Refuse Treatment. In: Beuchamp, T.L. (Ed.). Intending Death, pp. 109-130, Prentice Hall, ISBN 0131995553, Upper Saddle River, USA

Aristoteles (2009). The Nicomachean Ethics, Oxford University Press, ISBN 0199213610, Oxford, UK

Augustinus Aurelius (1909). De civitate Dei, University of California Libraries, ISBN 1125378921, Berkeley, USA

Bacon, F. (2000). The Advancement of Learning, Oxford University Press, ISBN 0198123485, Oxford, UK - New York, USA

Battin, M.P.; Leslie, F.P. \& Landesman, B.M. (2007). Death, Dying and the Ending of Life, Ashgate Publishing, ISBN 075462174X, Burlington, USA

Beauchamp, T.L. \& Childress, J.F. (2001). Principles of Biomedical Ethics, Oxford University Press, $5^{\text {th }}$ edition, ISBN 0195143329, Cambridge, UK - New York, USA

Beauchamp, T.L. (2003). End-of-Life Decision Making. In: Beauchamp, T.L. \& Walters, L. (Eds.). Contemporary Issues in Bioethics, $6^{\text {th }}$ edition, pp. 179-185, Thomson/Wadworth, ISSN 0534584411, Belmont..., USA

Beauchamp, T.L. \& Davidson, A.I. (1979). The Definition of Euthanasia, The Journal of Medicine and Philosophy, Vol. 4, No. 3 (September 1979), pp. 294-312, ISSN 17445019 
Beech, I. (1995). Suicide and Voluntary Active Euthanasia. Why the Difference in Attitude? Nursing Ethics, Vol. 2, No. 2 (June 1995), pp. 161-170, ISSN 09697330

Behnke, J.A. \& Bok, S. (Eds.). (1975). The Dilemmas of Euthanasia, Anchor Press, ISBN 0385097301, Garden City/N.Y., USA

Binding, K. \& Hoche, A.E. (1920). Freigabe der Vernichtung lebensunwerten Lebens: ihr Maß und ihre Form, Meiner, Jena, Germany

Birnbacher, D. (1995). Tun und Unterlassen, Reclam, ISBN 3150093929, Stuttgart, Germany

Bishop, J.P. (2006). Euthanasia, Efficiency, and the Historical Distintion Between Killing a Patient and Allowing a Patient to Die, Journal of Medical Ethics, Vol. 32, No. 4 (April 2006), pp. 220-224, ISSN 14734257

Bobbert, M. (2003). Sterbehilfe als medizinisch assistierte Tötung auf Verlangen. In: Düwell, M. \& Steigleder, K. (Eds.). Bioethik. Eine Einführung, pp. 314-322, Suhrkamp, ISBN 3518291971, Frankfurt am Main, Germany

Boyle, J. (1991). Who is Entitled to Double Effect? The Journal of Medicine and Philosophy, Vol. 16, No. 5 (October 1991), pp. 475-494, ISSN 03605310

Brock, D.W. (1992). Voluntary Active Euthanasia, The Hastings Center Report, Vol. 22, No. 2 (March-April 1992), pp. 10-22, ISSN 00930334

Brock, D.W. (1993). Life and Death: Philosophical Essays in Biomedical Ethics, Cambridge University Press, ISBN 0521417856, Cambridge, UK - New York, USA

Brock, D.W. (1999). Voluntary Active Euthanasia. In: Beauchamp, T.L. \& Walters, L. (Eds.). Contemporary Issues in Biomedical Ethics, 5th edition, pp. 296-305, Thomson, ISBN 0534504760, Belmont..., USA

Brody, B.A. (Ed.). (1989). Suicide and Euthanasia: Historical and Contemporary Themes, Kluwer Academic Publishers, ISBN 0792301064, Dordrecht, NL - Boston, USA

Callahan, D. (1999), When Self-Determination Runs Amok, In: Curzer, H.J. (Ed.). Ethical Theory and Moral Problems, pp. 718-726, Wardsworth, ISBN 534529747, Belmont, USA

Campbell, A.; Gillett, G. \& Jones, G. (2005). Medical Ethics, $4^{\text {th }}$ edition, Oxford University Press, ISBN 0195584872, Oxford, UK - New York, USA

Campbell, N. (1999). A Problem for the Idea of Voluntary Euthanasia, Journal of Medical Ethics, Vol. 25, No. 3 (June 1999), pp. 242-244, ISSN 14734257

Cantor, N.L. (1993). Advance Directives and the Pursuit of Death With Dignity, Indiana University Press, ISBN 025331304X, Bloomington, USA

Cavan, S. (2000). Euthanasia. The Debate Over the Right to Die, Rosen Publishing Group, ISBN 082393215X, New York, USA

Deigh, J. (1998). Physician-Assisted Suicide and Voluntary Euthanasia: Some Relevant Differences, The Journal of Criminal Law and Criminology, Vol. 88, No. 3 (Spring, 1998), pp. 1155-1165, ISSN 00914169

Diogenes Laertius (1999). Vitae philosophorum, Vol. 3, Sauer Verlag, ISBN 3598713193, Munich, Germany

Donagan, A. (1991). Moral Absolutism and the Double-Effect Exception, The Journal of Medicine and Philosophy, Vol. 16, No. 5 (October 1991), pp. 495-509, ISSN 03605310

Dowbiggin, I. (2007). A Concise History of Euthanasia: Life, Death, God and Medicine, Rowman \& Littlefeld Publishers, ISBN 0742531116, Lanham, USA

Downing, A.B. \& Smoker, B. (Eds.). (1986). Voluntary Euthanasia. Experts Debate the Right to Die, P. Owen, ISBN 0391033654, London, UK 
Draper, H. (1998). Euthanasia. In: Chadwick, R. (Ed.). Encyclopedia of Applied Ethics, Vol II., pp. 175-187, Academic Press, ISBN 012227066, San Diego..., USA

Eibach, U. (1998). Sterbehilfe: Tötung auf Verlangen? Brockhaus, ISBN 3417204178, Wuppertal, Germany

Eid, V. (Ed.). (1985). Euthanasie oder Soll man auf Verlangen töten? Grünewald, ISBN 3786711577, Mainz, Germany

Eigler, G. (Ed.). (1970). Platon - Werke. Griechisch und Deutsch, Wissenschaftliche Buchgesellschaft, ISBN 3534025741, Darmstadt, Germany

Emanuel, E.J. (1999). What Is the Great Benefit of Legalizing Euthanasia or PhysicanAssisted Suicide? Ethics, Vol. 109, No. 3 (April 1999), pp. 629-642, ISSN 00141704

Engelhardt, H.T. (1989). Death by Free Choice: Modern Variations on an Antique Theme. In: Brody, B.A. (Ed.). Suicide and Euthanasia: Historical and Contemporary Themes, pp. 251-279, Kluwer Academic Publishers, ISBN 0792301064, Dordrecht, NL - Boston, USA

England, E.B. (Ed.). (1975). The Laws of Plato, Arno Press, ISBN 0405073275, New York, USA

Euthanasia Definition (2011). Available at http:/ / www.euthanasia.com. Cited 18.03.2011

Ferguson, J.E. (2007). The Right to Die, Chelsea House Publishers, ISBN 0791092873, New York, USA

Firth, R. (1981). Euthanasia, RAIN (Royal Anthropological Institutes News), Vol . 45 (August 1981), pp. 1-4, ISSN 03076776

Fletcher, J.F. (1954). Morals and Medicine. The Moral Problems of: the Patient's Right to Know the Truth, Contraception, Artificial Insemination, Sterilization, Euthanasia, Princeton University Press, Princeton, USA

Fletcher, J.F. (1979). Humanhood. Essays in Biomedical Ethics. Prometheus Books, ISBN 0879751126, Bufallo, USA

Foot, Ph. (1977). Euthanasia, Philosophy and Public Affairs, Vol. 6, No. 2 (Winter 1977), pp. 85112, ISSN 10884963

Frey, R.G. (1999). Hume on Suicide, Journal of Medicine and Philosophy, Vol. 24, No. 4 (June July 1999), pp. 336-351, ISSN 17445019

Galton, F. (2006). Hereditary Genius. An Inquiry into Its Laws and Consequences, Prometheus Books, ISBN 1591023580, Amherst, USA (orig. London: Macmillan, 1869)

Galton, F. (1973). Inquiries into Human Faculty and Its Development, AMS Press, ISBN 0404081274, New York, USA (orig. London: Macmillan, 1883)

Gerrard, E. \& Wilkinson, S. (2005). Passive Euthanasia, Journal of Medical Ethics, Vol. 31, No. 2 (February 2005), pp. 64-68, ISSN 14734257

Gesang, B. (2008). Passive and Active Euthanasia: What is the Difference? The Hastings Center Report, Vol. 22, No. 2 (March-April 1992), pp. 34-38, ISSN 00930334

Graziani, R. (1969). Non-Utopian Euthanasia: An Italian Report, c. 1554, Renaissance Quarterly, Vol. 22, No. 4 (Winter 1969), pp. 329-333, ISSN 00344338

Haeckel, E. (1910). Anthropogenie oder Entwickelungsgeschichte des Menschen, Edelmann, $6^{\text {th }}$ edition, Leipzig, Germany (1 ${ }^{\text {st }}$ edition, Leipzig, 1874)

Hawryluck, L.A. \& Harvey, W.R.C. (2000). Analgesia, Virtue, and the Principle of Double Effect, Journal of Palliative Care, Vol. 16, Supplement (October 2000), pp. S24-30, ISSN 08258597 
Heide, van der, A. et al. (2003). End-of-Life Decision-Making in Six European Countries: Descriptive Study, Lancet, Vol. 362, No. 9381 (August 2, 2003), pp. 345-50, ISSN 01406736

Heide, van der, A. et al. (2007). End-of-Life Practices in the Netherlands under the Euthanasia Act. New England Journal of Medicine, Vol. 19, No. 356 (May 10, 2007), pp. 1957-1965, ISSN 00284793

Hippocrates (1923). Works (English and Greek, translated by W. H. S. Jones), Vol. 2, Harvard University Press, ISBN 0674995228, Cambridge, USA

Hume, D. (1985). Essays, Moral, Political, and Literary, Liberty Press, ISBN 0865970440, Indianapolis, USA

Humphry, D. \& Wickett, A. (1986). The Right to Die. Understanding Euthanasia, Harper \& Row, ISBN 0060155787, New York, USA

Husak, D.N. (1980). Omissions, Causation and Liability, The Philosophical Quarterly, Vol. 30, No. 121 (October 1980), pp. 318-326, ISSN 14679213

Chauncey, D.L. (Ed.). (1975). Percival's Medical Ethics. New York: R. E. Krieger Publishing, ISBN 0404133568 , New York, USA

Illhardt, F.J.; Heiss, H.W. \& Dornberg, M. (Eds.). (1998). Sterbehilfe - Handeln oder Unterlassen? Schattauer, ISBN 379451839X, Stuttgart, Germany

Jonsen, A.R. (1998). The Birth of Bioethics, Oxford University Press, ISBN 0195103254, Oxford, UK

Kamm, F.M. (1991). The Doctrine of Double Effect: Reflections on Theoretical and Practical Issues, The Journal of Medicine and Philosophy, Vol. 16, No. 5 (October 1991), pp. 571585, ISSN 03605310

Kamm, F.M. (1994). Action, Omission, and the Stringency of Duties, University of Pennsylvania Law Review, Vol. 142, No. 5 (May 1994), pp. 14931512, ISSN 19428537

Kamm, F.M. (1999). Physician-Assisted Suicide, the Doctrine of Double Effect, and the Ground of Value, Ethics, Vol. 109, No. 3 (April 1999), pp. 586-605, ISSN 00141704

Kant, I. (1990). Die Metaphysik der Sitten, Philipp Reclam, ISBN 3150045088, Stuttgart, Germany

Kant, I. (1996). Grundlegung zur Metaphysik der Sitten, Philipp Reclam, ISBN 315004507X, Stuttgart, Germany

Kant, I. (2011). Fundamental Principles of the Metaphysic of Morals. Available at http://www.gutenberg.org/. Cited 20.03.2011.

Keown, J. (2002). Euthanasia, Ethics, and Public Policy: An Argument Against Legalisation, Cambridge University Press, ISBN 0521804167, Cambridge, UK - New York, USA

Kinzbrunner, B.M. \& Policzer, J.S. (2010). End of Life Care. A Practical Guide, McGraw-Hill Professional Publishing, ISBN 0071545271, New York, USA

Klein, M. (2004). Voluntary Active Euthanasia and the Doctrine of Double Effect, Health Care Analysis, Vol. 12, No. 3 (September 2004), pp. 225-240, ISSN 10653058

Kohl, M. (1974). The Morality of Killing: Sanctity of Life, Abortion, and Euthanasia, Humanities Press, ISBN 0391001957, New York, USA

Kohl, M. (1992). Euthanasia. In: Becker, L.C. \& Becker, C.B. (Eds.). Encyclopedia of Ethics, Vol. I, pp. 335-339, Garland Publishing, ISBN 081530403X, New York, USA - London, UK 
Kohl, M. (2001). Euthanasia. In: Becker, L.C. \& Becker, C.B. (Eds.). Encyclopedia of Ethics, 2nd edition, Vol. I, pp. 492-498, Routledge, ISBN 0415936721, New York, USA - London, UK

Krämer,W. (1997). Hippokrates und Sisyphus - die moderne Medizin als Opfer ihres eigenen Erfolges. In: Kirch, W. \& Kliemt H. (Eds.). Rationierung im Gesundheitswesen, pp. 7-19, Roderer Verlag, Regensburg, Germany

Kruse, T. \& Wagner, H. (Eds.). (1986). Sterbende brauchen Solidarität, Beck, ISBN 3406311431, Munich, Germany

Kuře, J. (2007). Dobrá smrt. K filozofickému ujasnění pojmu eutanázie, Filozofia, Vol. 62, No. 3 (2007), pp. 223-234, ISSN 0046385X

Leenen, H. et al. (1998). Bill on Euthanasia and Assisting Suicide in the Netherlands, European Journal of Health Law, Vol. 5, No. 3 (September 1998), pp. 299-324, ISSN 15718093

Lenz, F. (1931). Menschliche Auslese und Rassenhygiene, Lehmanns Verlag, 3rd edition, Munich, Germany

Lewis, P. (2007). Assisted Dying and Legal Change, Oxford University Press, ISBN 0199212872, Oxford, UK

Lewy, G. (2011). Assisted Death in Europa and America, Oxford University Press, ISBN 0199746415, Oxford, UK - New York, USA

Lock, M. (1996). Death in Technological Time: Locating the End of Meaningful Life, Medical Anthropology Quarterly, Vol. 10, No. 4 (December 1996), pp. 575-600, ISSN 15481387

Luper, S. (2009). The Philosophy of Death, Cambridge University Press, ISBN 00521882491, Cambridge, UK - New York, USA

Maas, van der, P.J. et al. (1991). Euthanasia and Other Medical Decisions Concerning the End of Life, Lancet, Vol. 335, No. 8767, (September 1991), pp. 669-773, ISSN 01406736

Maas, van der, P.J. (1996). Euthanasia, Physician-Assisted Suicide, and Other Medical Practices Involving the End of Life in the Netherlands, 1990-1995, The New England Journal of Medicine, Vol. 335, No. 22 (November 28 1996), pp. 1699-1705, ISSN 00284793

Markson, D.S. (1969). The Punishment of Suicide - A Need for Change, Villanova Law Review, Vol. 14, No. 3 (1969), pp. 463-483, ISSN 00426229

Marx, C.F.H. (1952). Medical Euthanasia, Journal of the History of Medicine and Allied Sciences, Vol. 7, No. 4 (April 1952), pp. 401-416, ISSN 14684373

Materstvedt, L.J. et al. (2003). Euthanasia and Physician-Assisted Suicide: A View from An EAPC Ethics Task, European Journal of Palliative Care, Vol. 10, No. 2, p. 63, ISSN 1479-0793

McLachlan, H.V. (2008). The Ethics of Killing and Letting Die: Active and Passive Euthanasia, Journal of Medical Ethics, Vol. 34, No. 8 (August 2008), pp. 636-638, ISSN 14734257

McMahan, J. (1993). Killing, Letting Die, and Withdrawing Aid, Ethics, Vol. 103, No. 2 (January 1993), pp. 250-279, ISSN 00141704

Michalsen, A. \& Reinhart, K. (2006). "Euthanasia": A Confusing Term, Abused Under the Nazi Regime and Misused in Present End-of-Life Debate, Intensive Care Medicine, Vol. 32, No. 9 (September 2006), pp. 1304-1310, ISSN 03424642

Montaigne, de M. (1946). The Essays, Oxford University Press, New York, USA 
Moody, J. (2003). Euthanasia: A Need for Reform, Nursing Standard, Vol. 17, No. 25 (March 2003), pp. 40-44, ISSN 00296570

More, T. (2011). Utopia. Available at http:/ / www.gutenberg.org/. Cited 20.03.2011.

Müller, A.W. (1997). Tötung auf Verlangen: Wohltat oder Untat? Kohlhammer, ISBN 317015110X, Stuttgart, Germany

Mystakidou, K. et al. (2005). The Evolution of Euthanasia and Its Perceptions in Greek Culture and Civilization, Perspectives in Biology and Medicine, Vol. 48, No. 1 (Winter 2005), pp. 95-104, ISSN 15298795

Nayernouri, T. (2011). Euthanasia, Terminall Illness and Quality of Life, Archives of Iranian Medicine, Vol. 14, No. 1 (January 2011), pp. 54-55, ISSN 10292977

Nietzsche, F. (1997). Werke, Phaidon Verlag, ISBN 3888511240, Essen, Germany

Onwuteaka-Philipsen, B.D. et al. (2003), Euthanasia and Other End-of-Life Decisions in the Netherlands in 1990, 1995, and 2001, Lancet, Vol. 362, No. 9381 (August 2003), pp. 395-399, ISSN 01406736

Pöltner, G. (2006). Grundkurs Medizin-Ethik, 2nd edition, Facultas, ISBN 3850767965, Wien, Austria

Quaghebeur, T. et al. (2009). Nursing and Euthanasia: A Review of Argument-Based Ethics Literature, Nursing Ethics, Vol. 16, No. 4 (July 2009), pp. 466-486, ISSN 09697330

Quill, T.E. \& Battin, M.P. (2004). Physician-Assisted Dying. The Case for Palliative Care and Patient Choice. Johns Hopkins University Press, ISBN 0801880696, Baltimore, USA

Quill, T.E. et al. (1997). The Rule of Double Effect: A Critique of its Role in End-of-Life Decision Making, New England Journal of Medicine, Vol. 337, No. 24 (December 11, 1997), pp. 1768-1771, ISSN 00284793

Rachels, J. (1975). Active and Passive Euthanasia, The New England Journal of Medicine, Vol. 292, No. 2 (January 9, 1975), pp. 78-80, ISSN 00284793

Riley, J.; George, R. \& Finlay, I. (2009). It is Our Responsiblity to Promote Care, Not Killing, Euroepan Journal of Palliative Care, Vol. 16, No. 3 (May 2009), p. 109, ISSN 14790793

Ritzel, G. (Ed.). (1998). Beihilfe zum Suizid - Ein Weg im Streit um Sterbehilfe? Roderer, ISBN 3890732445, Regensburg, Germany

Seneca, L.A. (1965). Ad Lucilium epistulae morales, Oxford University Press, ISBN 0198146493, Oxford, UK

Sheldon, T. (1994). Dutch Argue that Mental Torment Justifies Euthanasia. The British Medical Journal, Vol. 308, No. 6926 (February 12, 1994), p. 431, ISSN 09598146

Schöne-Seifert, B. (1997). Die Grenzen zwischen Töten und Sterben lassen, Jahrbuch für Wissenschaft und Ethik, Vol. 2, pp. 205-226, ISSN 14309017

Simon, A. (2003). Sterbehilfe. In: Düwell, M. \& Steigleder, K. (Eds.). Bioethik. Eine Einführung, pp. 306-313, Suhrkamp, ISBN 3518291971, Frankfurt am Main, Germany

Spaemann, R. \& Fuchs, T. (1997). Töten oder sterben lassen? Herder, ISBN 3451045710, Freiburg im Breisgau, Germany

Sporken, P. (1988). Die Sorge um den kranken Menschen, Patmos, ISBN 3491772508, Düsseldorf, Germany

Sporken, P. (Ed.). (1990). Was Sterbende brauchen, Herder, ISBN 3451196182, Basel, Switzerland

Stewart, H.L. (1918). Euthanasia, International Journal of Ethics (1890-1938), Vol. 29, No. 1 (October 1918), pp. 48-62, ISSN 1526422X 
Stolberg, M. (2008). Two Pioneers of Euthanasia around 1800, The Hastings Center Report, Vol. 38, No. 3 (May-June 2008), pp. 19-22, ISSN 00930334

Suetonius (1997). Lives of the Twelve Caesars, Wodsworth Editions Limited, ISBN 185326475X, Ware, UK

Sunstein, C.R. (1997). The Right to Die, The Yale Law Journal, Vol. 106, No. 4 (January 1997), pp. 1123-1163, ISSN 00440094

The Belgian Ministry of Justice. (2002). The Belgian Act on Euthanasia of 28 May 2002. Available at http:/ / www.ejustice.just.fgov.be. Cited 27.03.2011.

The Convention for the Protection of Human Rights and Dignity of the Human Being with Regard to the Application of Biology and Medicine (1997). Available at http:/ / www.europarl.europa.eu/. Cited 26.03.2011.

The Charter of Fundamental Rights of the European Union (2000). Available at http://www.europarl.europa.eu/. Cited 26.03.2011.

Thomas Aquinas (1964). Summa theologica, McGraw-Hill, New York, USA

Van Zyl, L. (2000). Death and Compassion: A Virtue-Based Approach to Euthanasia, Ashgate, ISBN 0754612317, Aldershot, UK

Vanderpool, H.Y. (2004). Life-Suistaining Treatment and Euthanasia. In: Post, S.G. (Ed.), Encylopedia of Bioethics, Vol. III, pp. 1421-1432, Thomson \& Gale, $3^{\text {rd }}$ edition, ISBN 0028657748, New York, USA

Vermaat, J.A.E. (2002). 'Euthanasia' in the Third Reich: Lessons for today? Ethics $\mathcal{E}$ Medicine. An International Journal of Bioethics, Vol. 18, No. 1. (Spring 2002), pp. 21-32, ISSN 0266688X

Wal, van der, G. \& Dillmann, R.J.M. (1994). Euthanasia in the Netherlands, The British Medical Journal, Vol. 308, No. 6940 (May 21, 1994), pp. 1346-1349, ISSN 09598146

Walton, D. (1976). Active and Passive Euthanasia, Ethics, Vol. 86, No. 4 (July 1976), pp. 343349, ISSN 00141704

Warnock, M. \& Macdonald, E. (2008). Easeful Death: Is There a Case for Assisted Dying? Oxford University Press, ISBN 0199539901, Oxford, UK - New York, USA

Watts, D.T. \& Howell T. (1992). Assisted Suicide Is Not Voluntary Active Euthanasia, The Journal of the American Geriatrics Society, Vol. 40, No. 10 (October 1992), pp. 10431046, ISSN 15325415

Weikart, R. (2002). Darwinism and Death: Devaluing Human Life in Germany 1859-1920, Journal of the History of Ideas, Vol. 63, No. 2 (April 2002), pp. 323-344, ISSN 10863222

Wiesing, U. (Ed.). (2004). Ethik in der Medizin. Reclam Verlag, ISBN 3150183413, Stuttgart, Germany

Wilshaw, C. (1974). The Right to Die. A Rational Approach to Voluntary Euthanasia, British Humanist Association, ISBN 0901825085, London, UK

Wolf, S.M. (2008). Confronting Physician-Assisted Suicide and Euthanasia: My Father's Death, The Hastings Center Report, Vol. 38. No. 5 (September - October, 2008), pp. 24-26, ISSN 00930334

World Medical Association (2011). Policies. Available at http://www.wma.net/. Cited 21.03.2011.

Wreen, M. (1988). The Definition of Euthanasia, Philosophy and Phenomenological Research, Vol. 48, No. 4 (June 1988), pp. 637-653, ISSN 19331592

Young, R. (2007). Medically Assisted Death, Cambridge University Press, ISBN 0521880246, Cambridge, UK 


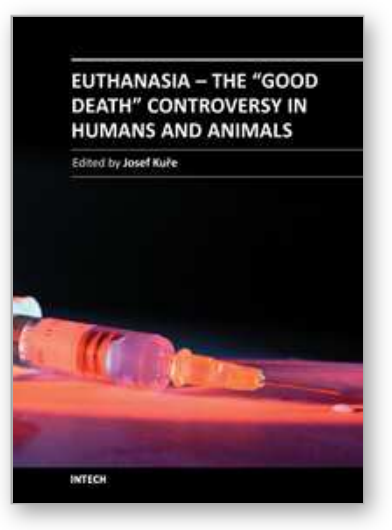

\author{
Euthanasia - The "Good Death" Controversy in Humans and \\ Animals \\ Edited by Prof. Josef KuÅ ${ }^{T M} \mathrm{e}$
}

ISBN 978-953-307-260-9

Hard cover, 248 pages

Publisher InTech

Published online 15, September, 2011

Published in print edition September, 2011

No one really wants to die, or do they? From classical times to our post-modern era of medical high tech, societies have struggled with the thorny issue of euthanasia, and what it entails. Who shall be entitled to a "good death" and in what form shall it arrive? This book provides the reader with insight and enlightenment on the medical, philosophical, social, cultural and existential aspects of "good death" amid our digitized, individualized and ageing society, hampered by rising health care costs but unchained from one standardized level of care.

\title{
How to reference
}

In order to correctly reference this scholarly work, feel free to copy and paste the following:

Josef Kuře (2011). Good Death Within Its Historical Context and as a Contemporary Challenge: A Philosophical Clarification of the Concept of "Euthanasia", Euthanasia - The "Good Death" Controversy in Humans and Animals, Prof. Josef KuÅTMe (Ed.), ISBN: 978-953-307-260-9, InTech, Available from: http://www.intechopen.com/books/euthanasia-the-good-death-controversy-in-humans-and-animals/gooddeath-within-its-historical-context-and-as-a-contemporary-challenge-a-philosophical-clarificati

\section{INTECH}

open science | open minds

\section{InTech Europe}

University Campus STeP Ri

Slavka Krautzeka 83/A

51000 Rijeka, Croatia

Phone: +385 (51) 770447

Fax: +385 (51) 686166

www.intechopen.com

\section{InTech China}

Unit 405, Office Block, Hotel Equatorial Shanghai

No.65, Yan An Road (West), Shanghai, 200040, China

中国上海市延安西路65号上海国际贵都大饭店办公楼405单元

Phone: +86-21-62489820

Fax: +86-21-62489821 
(C) 2011 The Author(s). Licensee IntechOpen. This chapter is distributed under the terms of the Creative Commons Attribution-NonCommercialShareAlike-3.0 License, which permits use, distribution and reproduction for non-commercial purposes, provided the original is properly cited and derivative works building on this content are distributed under the same license. 